\title{
Mauritius: African Success Story
}

\author{
Jeffrey Frankel \\ CID Working Paper No. 234 \\ April 2012
}

(C) Copyright 2012 Jeffrey Frankel, and the President and Fellows of Harvard College

\section{Working Papers Center for International Development at Harvard University}




\title{
Mauritius: African Success Story
}

\author{
Jeffrey Frankel, Harvard University \\ NBER Project on African Successes
}

This paper was presented at the NBER Conference on African Successes, Accra, Ghana, July 1820, 2010. The author would like to thank for research assistance Oyebola Olabisi, Jesse Schreger, Diva Singh and Cristobal Marshall. He benefited from numerous discussions with the people of Mauritius, but is especially indebted to Ali Mansoor.

Among many others from whom he absorbed ideas are Vinaye dey Ancharaz, Abhijit Banerjee, Arvind Subramanian in academia; Central Bank Governor Rundheersing Bheenik, Prime Minister Navin Ramgoolam, and Finance Minister Ramakrishna Sithanen in the government; and others in Mauritius including Nando Bodha and Anubhava Katiyar.

The author also thanks for comments on an earlier draft Jorge de Macedo, other participants at the Accra conference, and Avnish Gungadurdoss. This study was part of a NBER project on African Successes, organized by Sebastian Edwards, Simon Johnson and David Weil.

\begin{abstract}
Mauritius is a top performer among African countries. It developed a manufacturing sector soon after independence and has managed to respond well to new external shocks. What explains this success? This paper draws on the history of the island, the writings of foreign economists, the ideas of locals, and the results of econometric tests. Mauritius has mostly followed good policies. They include: creating a well-managed Export Processing Zone, conducting diplomacy regarding trade preferences, spending on education, avoiding currency overvaluation, and facilitating business. The good policies can in turn be traced back to good institutions. They include: forswearing an army, protecting property rights (particularly non-expropriation of sugar plantations), and creating a parliamentary structure with comprehensive participation (in the form of representation for rural districts and ethnic minorities, the "best loser system," ever-changing coalition governments, and cabinet power-sharing). But from where did the good institutions come? They were chosen around the time of independence in 1968. Why in Mauritius and not elsewhere? Luck?

Some fundamental geographic and historical determinants of trade and rule of law help explain why average income is lower in Africa than elsewhere, and trade and rule of law help explain performance within Africa just as they do worldwide. Despite these two econometric findings, the more fundamental determinants are not much help in explaining relative performance within Africa. Fundamental determinants that work worldwide but not within Africa are remoteness, tropics, size and fragmentation. (Access to the sea is the one fundamental geographic determinant of trade and income that is always important.) A case in point is the high level of ethnic diversity in Mauritius, which in many places would make for dysfunctional politics. Here, however, it brings cosmopolitan benefits. The institutions manage to balance the ethnic groups; none is excluded from the system. It is intriguing that the three African countries with the highest governance rankings (Mauritius, Seychelles and Cape Verde) are all islands that had no indigenous population. It helps that everyone came from somewhere else.
\end{abstract}




\section{Mauritius: African Success Story}

Some might be tempted to put a question mark after a title like "Mauritius: African Success Story.” But this would only be because some ask if the country off the eastern coast of Madagascar is truly African, in light of its unusual ethnic composition. ${ }^{1}$

There cannot be much doubt about the word "story." The country's story is a fascinating one.

Nor can there by much doubt that it is a "success": of all countries identified as being in the geographical region of Africa, Mauritius appears at the top of the governance rankings, as Table 1 shows. The Rule of Law index from World Governance Indicators puts Mauritius first in sub-Saharan Africa, followed by Botswana and Cape Verde. The Index of African Governance compiled by Rotberg and Gisselquist (2009), which attempts to rely less on subjective measures, again puts Mauritius in the number one spot, followed by Seychelles, Cape Verde and Botswana. ${ }^{2}$ Mauritian growth in GDP per capita rate averaged 5.4\% over the period 1970-2010, during which the growth rate in the rest of Africa was only about 1\%. By 2010 Mauritius had achieved a per capita income of about $\$ 7,000$ at current exchange rates. (The number is higher, of course, in PPP terms: \$11,000.) An oil-rich country such as Equatorial Guinea has higher income; but as a result of poor governance few people outside the elite enjoy improved quality of life. The Human Development Index from the United Nations Development Program, a more comprehensive measure, classifies Mauritius in the "High Human Development" quartile globally: It ranks number 81 out of 182 countries, well ahead of other African countries. ${ }^{3}$ Life expectancy is 72.8 years, for example. ${ }^{4}$

Others may wonder if the country is too small to hold important lessons for typical-sized countries. The land area is only 1,865 square kilometers, or 720 square miles. But given the population of $1 \frac{1 / 4}{4}$ million and the current relatively high level of income per capita, GDP puts the country at the median among African countries in economic size, ahead of Namibia. ${ }^{5}$

\footnotetext{
${ }^{1}$ Today, $68 \%$ of the population has Indian forbears. Even inside this share are ethnic cleavages between Hindu and Muslim, and between those whose ancestors immigrated from the Ganges plain and those who emigrated from elsewhere (especially Tamils). Major remaining shares include Creoles, FrancoMauritians, and Sino-Mauritians. [An ethnic composition that features a small number of large ethnic groups is usually considered a negative factor for development.]

${ }^{2}$ The next countries in the governance rankings are South Africa, Namibia, and Ghana, with the sequence depending on the precise measure and year.

${ }^{3}$ Tiny Seychelles is ahead, at 57. The next nearest competitors in sub-Saharan Africa are: Gabon at 103, Equatorial Guinea at 118, Cape Verde at 121, Botswana at 125, South Africa at 129, and Sao Tome and Principe at 131. Most fill out the bottom ranks. Human Development Report 2009, UNDP. At http://hdr.undp.org/en/statistics/.

${ }^{4}$ World Development Indicators (2009) and Rotberg and Gisselquist (2009) show the Seychelles as just surpassing Mauritius in lifespan in 2007. Followed by Cape Verde, Western Sahara, Sao Tome and Principe, Comoros, Mauritania, Senegal and Ghana. Source: United Nations, for 2005-2010. Table 2 reports additional statistics for all African countries, standardized for the common year 2006.

5 Namibia has twice the population and 400 times the land area. Total GDP in Mauritius also surpassed Mali, Madagascar and the Congo in 2009.
} 
Table 1: Sub-Saharan Countries Ranked by Governance, with other indicators

\begin{tabular}{|c|c|c|c|c|}
\hline $\begin{array}{l}\text { Index of African } \\
\text { Governance } \\
\text { Ranking (2007) }\end{array}$ & Country & $\begin{array}{l}\text { GDP per capita, } \\
\text { PPP in constant } 2005 \\
\text { Interntl. \$ (2008) }\end{array}$ & $\begin{array}{l}\text { UN Human } \\
\text { Development } \\
\text { Ranking (2007) }\end{array}$ & $\begin{array}{c}\text { World Governance } \\
\text { Indicators, Rule of Law } \\
\text { Index Ranking (2008) }\end{array}$ \\
\hline 1 & Mauritius & 11412 & 2 & 1 \\
\hline 2 & Seychelles & 19758 & 1 & 5 \\
\hline 3 & Cape Verde & 2957 & 5 & 3 \\
\hline 4 & Botswana & 12537 & 6 & 2 \\
\hline 5 & Ghana & 1351 & 18 & 7 \\
\hline 6 & Namibia & 5909 & 7 & 4 \\
\hline 7 & South Africa & 9343 & 8 & 6 \\
\hline 8 & Sao Tome \& Principe & 1615 & 9 & 18 \\
\hline 9 & Gabon & 13461 & 3 & 24 \\
\hline 10 & Benin & 1361 & 27 & 22 \\
\hline 11 & Malawi & 744 & 26 & 10 \\
\hline 12 & Gambia & 1259 & 33 & 8 \\
\hline 13 & Senegal & 1656 & 31 & 12 \\
\hline 14 & Madagascar & 974 & 14 & 15 \\
\hline 15 & Burkina Faso & 1072 & 41 & 14 \\
\hline 16 & Tanzania & 1201 & 17 & 9 \\
\hline 17 & Mauritania & $1810^{1}$ & 20 & 30 \\
\hline 18 & Lesotho & 1444 & 23 & 11 \\
\hline 19 & Zambia & 1253 & 29 & 16 \\
\hline 20 & Comoros & 1081 & 11 & 31 \\
\hline 21 & Rwanda & 949 & 32 & 17 \\
\hline 22 & Kenya & 1432 & 15 & 28 \\
\hline 23 & Uganda & 1077 & 22 & 19 \\
\hline 24 & Niger & 631 & 46 & 27 \\
\hline 25 & Mali & 1043 & 43 & 13 \\
\hline 26 & Mozambique & 774 & 37 & 25 \\
\hline 27 & Djibouti & 1975 & 21 & 21 \\
\hline 28 & Cameroon & 2027 & 19 & 29 \\
\hline 29 & Togo & 767 & 25 & 26 \\
\hline 30 & Sierra Leone & 723 & 45 & 32 \\
\hline 31 & Guinea-Bissau & 496 & 38 & 40 \\
\hline 32 & Ethiopia & 802 & 36 & 23 \\
\hline 33 & Nigeria & 1939 & 24 & 34 \\
\hline 34 & Burundi & 354 & 39 & 33 \\
\hline 35 & Liberia & 358 & 34 & 36 \\
\hline 36 & Equatorial Guinea & 31309 & 4 & 39 \\
\hline 37 & Swaziland & 4551 & 12 & 20 \\
\hline 38 & Congo (Brazzaville) & 3647 & 10 & 35 \\
\hline 39 & Guinea & 975 & 35 & 45 \\
\hline 40 & Zimbabwe & $185^{2}$ & N/A & 47 \\
\hline 41 & Angola & 5375 & 13 & 38 \\
\hline 42 & Eritrea & 592 & 30 & 37 \\
\hline 43 & C.A.R. & 685 & 44 & 41 \\
\hline 44 & Cote d'Ivoire & 1526 & 28 & 43 \\
\hline 45 & Congo (DR) & 290 & 42 & 46 \\
\hline 46 & Chad & 1234 & 40 & 44 \\
\hline 47 & Sudan & 1990 & 16 & 42 \\
\hline 48 & Somalia & & N/A & 48 \\
\hline
\end{tabular}

Notes: Ranking is among African countries excluding North Africa. $\quad{ }^{1}$ Data from $2007{ }^{2}$ Data from 2005 
Still others may wonder if the uniqueness of the story of Mauritius prevents generalizing to lessons that can be useful elsewhere. Of course every country is unique. If econometricians have run "two million cross section regressions" looking for the determinants of countries' economic performance ${ }^{6}$, it sometimes seems that others have complained two million times that the institutional, cultural and historical particularities of individual countries can never be captured by the data fed into a computer. This paper uses cross-country regressions as one input into the analysis - but only one. Two other kinds of inputs enter as well. One is the relevant economic, political and historical literature. Another kind of input is what the author -- with no previous background in Mauritius -- learned from exploring the country.

The many global econometric cross-country studies have produced a variety of important conclusions, notwithstanding their limitations and ambiguities. Some of the more robust findings include that remoteness, landlockedness, tropical location, and small population size ${ }^{7}$, are bad for economic performance, other things equal. These variables help explain why incomes are lower in Africa than in other parts of the world. Access to the sea, education, and national saving tend to be good for economic performance. High population density is often bad. Two of the most consequential findings are that openness to trade and the quality of institutions are major determinants of economic performance, but there are valid questions regarding the measurement of those two variables, and about the exogeneity of the relationships. Clearly a major reason that remoteness and landlockedness hurt economies is that they impede international trade. A common finding is a negative dummy variable for Africa. It often can be attributed to some of the other variables, however, especially tropical location, ${ }^{8}$ as becomes evident when the econometrician controls for them and the apparent Africa effect disappears.

While some of these variables may help explain the negative dummy for Africa, they do not necessarily help explain variation within Africa. Indeed, when using regression analysis to learn about differences in growth performance among African countries, one major finding below is that many of the variables that are most significant on global data sets do nothing for us within this continent.

The reader who has looked at Table 1 may have noticed a striking fact: not only is the highest performer in Africa reported to be a small island country (Mauritius), but so are numbers 2 and 3 (Seychelles and Cape Verde, respectively). Not until we get to fourth place do we see a country on the mainland (Botswana) and not until fifth place a country of substantial size (Ghana, in 2008). Is it just a coincidence that the top

\footnotetext{
${ }^{6}$ Sala-i-Martin (1997).

${ }^{7}$ Frankel and Romer (1999, Table 3), to take just one example.

${ }^{8}$ Probably the best interpretation of why tropical location seems to be bad for economic growth is the presence of malaria and other tropical diseases. Sachs (2003) shows that specific determinants of malaria are correlated with slow growth across countries.
} 
performers are island countries? There exists at least one small African island country with poor performance: the Comoros. What explains the difference? ${ }^{9}$

Island countries provide an intriguing sub-set of self-contained data points. There is less likely to be an issue of endogenous borders, for example. The econometric analysis of the determinants of economic performance in this paper includes a cross section of island countries, before we turn to a within-Africa data set.

We begin with a short history of Mauritius, however. Next comes an overview of the competing hypotheses that others have put forward to explain Mauritian success. Then the econometrics, followed by an attempt to put everything together. When we are done, we will not be able to claim a definitive answer as to the single reason for the island's success, nor will we ever attempt to answer whether it is African. But the story will be of interest, or so the author hopes. Most importantly, notwithstanding the uniqueness of the country, there are potentially valuable lessons for others seeking to achieve economic development in Africa.

\section{A Brief History of the Island}

Our account will just briefly hit the highlights, but will slow down a bit when we get to the post-independence history.

\section{Globalization at its Worst}

The first two centuries of Mauritius' history could be described as "globalization at its worst." $"$ The Dutch arrived in 1598 and the Dutch East India Company left a settlement in 1638 . They immediately stripped the island of its ebony trees, using slaves imported from Madagascar for the work, and famously killed off the dodo birds. Today, less than $1 \%$ of the indigenous forests are left. When the Dutch decamped for the Cape Colony in 1710, they left the island nothing useful but its name.

In 1721 the French landed. A competent governor Bertrand Mahe de Labourdonnais built a port/capital at Port Louis on the western coast and made many improvements in the land that the colonizers called Ile de France. They began to grow sugar for export - the first factory was built in 1744 -- and other crops. But the expanding sugar economy depended on slavery, the ultimate evil of the age. As if to complete a list of evils of globalization, passing ships occasionally brought either pirates or cholera, wreaking havoc on the population.

The island officially passed from France to Britain with the defeat of Napoleon in 1814. ${ }^{11}$ The British valued their new possession, but as a coveted way station on the

\footnotetext{
${ }^{9}$ Madagascar is an island, but we are not counting it as small. As noted, Equatorial Guinea shows high income per capita, but consistent with Natural Resource Curse the benefits from its oil discoveries have gone to the elite rather than the general population. In any case, only part of it is an island.

${ }^{10}$ I am counting from 1638 . The island was visited by Arabs one or more times in the seventh to ninth centuries, but they did not stay. The same with the Portuguese in the early $16^{\text {th }}$ century. This section of the paper draws in part on Lutz and Wils (1990) and Selvon (2005).

${ }^{11}$ Ironically, the French navy in 1810 scored the strongest of its very few victories of the Napoleonic Wars in the Battle of Grand-Port, on the eastern edge of Mauritius. But de facto possession of the island passed to the British later that year. 2010 is the $200^{\text {th }}$ anniversary.
} 
route to India and the Far East. They had no particular desire to settle the island, and were happy to leave the Franco-Mauriciens in place as the land-owning elite. The French Napoleonic code was retained, and still constitutes an important component of the legal system.

Slavery had already been abolished in the British Empire in 1807. The French landowners were reluctant to comply, however, and it wasn't until 1835 that slavery was finally ended on the island. The abolition of slavery marks the end of what I am calling the period of globalization at its worst. ${ }^{12}$

\section{Globalization at Its Best}

The next phase of Mauritian history began with a problem for the sugar-based economy. The abolition of slavery had left a shortage of labor. The freed slaves were understandably reluctant to go to work for their former masters. Who would work the plantations? The solution was a "Great Experiment": indentured workers were brought from India. From 1849 to 1923, a half million indentured Indian laborers passed through the immigration depot at the dock called Aaprivasi Ghat, the Ellis Island of Mauritius. Although their lot was hard, most of them chose it voluntarily because the conditions were better than what they were leaving behind. ${ }^{13}$ Production and exports from the plantations grew rapidly. The experiment was sufficiently successful that it was copied in other sugar-growing parts of the world such as Fiji and the Caribbean.

Eventually locals and even non-whites gained some political rights. Under the 1886 Constitution, which lasted 60 years, the British governor allowed a Creole elite to join the Franco-Mauritians among the national representatives. When a new constitution extended the franchise to all adults who could write in 1948, the Indian-dominated Labour Party suddenly won a majority in the Legislative Council seats. Its members were mainly rural workers and its platform was mainly Socialist. It was opposed by the Franco-Mauriciens, who accurately described themselves as "oligarchs," and who feared "Hindu hegemony." This phrase referred to what the majority ethnic group were expected to do if and when the country became independent, which the FrancoMauriciens opposed.

The Labour Party became more moderate under the leadership of Seewoosagur Ramgoolam. By 1960 it had renounced its previous position that the sugar plantations should be nationalized. ${ }^{14}$ This decision was to prove a key turning point in several respects. First, it helped establish the important precedent of safeguarding property rights. Second, it contrasted with other African countries that have either expropriated natural resources, taxed them away, or discouraged production through other devices such as marketing boards. Third, it eventually helped reconcile the Franco-Mauritians to independence.

\footnotetext{
${ }^{12}$ Many slaves had escaped to the wild over the years. Reportedly, when British soldiers came to bring news of their liberation, some of the escapees thought they were to be arrested, and so instead jumped to their deaths over the vertical sides of the mountain that was thenceforth called Le Morne.

13 In his novel Sea of Poppies, Amitav Ghosh describes a variety of circumstances that would inspire residents of the Ganges Plain to seek a better life in far-off Mauritius.

14 Selvon (2005, p. 404).
} 


\section{Independence}

In the early 1960s the British prepared for independence. ${ }^{15}$ But communal or sectarian tensions were strong. Creoles, the descendants of the original slaves, many of whom had acquired positions in the civil service and in the growing private sector, aligned with Franco-Mauritians in their fears regarding independence, adding to the voting strength of the latter. Chinese, Muslim and Tamil minorities too were afraid that those Hindus descended of immigrants from the Ganges Plain would dominate an independent country. The Mauritian Social Democratic Party (PMSD), composed of Franco-Mauritians and Creoles, lost elections to the Hindu-dominated Labour Party in 1967. This election confirmed the narrowly drawn fault lines regarding the independence issue: only 55\% voted for the independence platform. Riots along ethnic lines took place periodically in the 1960s, especially as the date of independence drew near. The Labour Party government had to call in British troops to restore order in January 1968.

Mauritius became an independent country in March 1968, with Ramgoolam as Prime Minister. He had won respect by avoiding divisive appeals and cooperating with all factions. He was to serve in that post for 14 years.

The PMSD boycotted the independence ceremony. It soon became reconciled to independence and the need for nation building, however, to some extent reassured by minority rights, and especially pushed by two powerful constituencies who favored stability: business leaders including plantation owners (who were financial backers of the party) together with the foreign diplomatic community. The PMSD joined in a series of changing coalition governments. All governments have been coalitions; each has included either Labour, the PMSD, or often both. The precedent that the parties must enter coalitions was set by the British governor, before independence.

The leftist niche was staked out by a new party, the Mouvement Militant Mauricien (MMM). The government responded in a heavy-handed way in 1971, first by postponing elections scheduled for the following year and then, when the MMM called strikes, by imprisoning its leader, a Franco-Mauricien named Paul Bérenger. The strategy seemed to work, at any rate. Bérenger subsequently moved to the right, perhaps as the policies of the ruling party were seen to be successful. (Economic growth averaged over 8\% during the years 1970-75.) Eventually Bérenger entered a coalition government with Anerood Jugnauth, when he was elected the second Prime Minister in 1982. Jugnauth served through 1995, in six coalition governments.

There are many parties, but two broad alliances usually dominate: one built around Labour, the MLP, and the other built around the MMM. The son of the founding premier, Navin Ramgoolam, at the head of Labour, became the third Prime Minister from 1995 to 2000 and was returned to office in 2005, where he is still serving.

15 This section draws on Bowman (1991, 33-42), Brautigam (1999a, b), Bunwaree and Kadenally (2006), Selvon (2005) and Simmons (1982), among others. 


\section{Which colonial heritage?}

Some economists and historians have sought to discern if one national brand of colonialism in Africa and elsewhere left behind better institutions than another. ${ }^{16}$ This test would be impossible to perform in the case of Mauritius, because of the impossibility of saying who left the colonial heritage. The Dutch? They first colonized the island, and named it. The French? They left the landowning elite and gave the island its dominant language. The British? Cars drive on the left and, remarkably, the country's Supreme Court is Britain's Privy Council, even though it became a Republic -- Queen Elizabeth ceased to be the head of state - in 1992. Or perhaps it could be described as India's colony. Three languages appear on the money: English, Hindi, and Tamil.

\section{Stages of development}

The traditional three stages of development worldwide feature gradual shifts in the composition of a country's economy, from the primary sector to manufactures, and then on to the service economy. This stylized model happens to fit Mauritius in a literal way. The commodities at the primary stage were agricultural, particularly sugar, as we have seen. Industrialization began in the 1970s, consisting largely of textiles and apparel. More recently, the desired and actual share of services has risen, especially tourism but also financial services, information and computer technology (ICT), and others. When economists ponder the island's success, they are usually talking about the solid achievement of that critical first stage of development: labor-intensive manufacturing, especially clothing exports. ${ }^{17}$ But we need equally to consider the subsequent phase of adaptation to trade shocks, especially the decline of clothing export markets.

\section{Adapting to external shocks}

While globalization carries gains from trade and other benefits, it also can also increase exposure to external fluctuations. Mauritius has experienced many external shocks in its history, inevitably suggesting the metaphor of a small ship on stormy seas. Whether through luck or skill, however, the country has usually been able to adapt to changed circumstances over the years. Consider four.

\section{(1) Labor shortage}

We have already discussed the big adaptation to the labor shortage on the sugar plantations that followed the abolition of slavery in 1835: the import of indentured workers from India.

\section{(2) Independence}

The second big shock was independence in 1968, under inauspicious conditions that will be elaborated in the next section of the paper. The country soon achieved tradeled growth in the 1970s, despite protectionist import policies.

\footnotetext{
16 For example, Feyrer and Sacerdote (2009).

17 Basic manufactures at the beginning also included wigs, toothpaste, and simple electronics, among other things.
} 


\section{(3) The 1974-80 increases in world oil price.}

Like most other oil-importing developing countries, Mauritius initially responded to its higher import bill by borrowing, running large current account deficits in the late 1970s. But it undertook successful adjustment ahead of most of the others. ${ }^{18}$ The adjustment took place in macroeconomic policy, when it devalued twice in compliance with IMF programs, ${ }^{19}$ as well as in microeconomic policy, featuring an important trade reform in 1984, ${ }^{20}$ consistent with a World Bank Structural Adjustment Facility. The reforms were implemented over three successive governments; a number of observers have highlighted what this says about the stability of the political system and its ability to do what is best for the country even while simultaneously squabbling furiously over personal and factional politics. ${ }^{21}$ There followed a period of strong economic performance that can be said to have carried the country into tiger status by the end of the 1990s.

\section{(4) Further trade shocks over the years 2004-09.}

The worst of the latter day trade shocks was the end of favored treatment abroad of its most important exports: the loss of sugar preferences in 2004 and the loss of MFA clothing preferences around the same time, as the Multi-Fibre Agreement (MFA) system was dismantled, the world market became free and open, and low-wage manufacturers in China displaced textiles and apparel in many developing countries. ${ }^{22}$ In Mauritius the sector suffered a $30 \%$ fall in output and $25 \%$ drop in employment. The balance of payments deficit, budget deficit, and unemployment all deteriorated. The adverse trend in the terms of trade continued with the rise in world prices of oil and food over the period 2003-08. Finally the great global recession hit all export-oriented countries in 2008-09.

The incoming Labour government that was returned to power in 2005 responded to the loss of trade preferences and current account deficit in several ways. ${ }^{23}$ A multifaceted reform program in 2006 included a Business Facilitation Act to eliminate obstacles to investment and hiring, steps to make it easier for desired immigrants to become citizens ${ }^{24}$, and a simplified tax system with a flat $15 \%$ tax rate for individuals and companies. Soon the government was able to claim tangible results: (i) the country climbed even higher in international rankings of climate for business ${ }^{25}$, and (ii) the budget deficit fell, so that by 2007 the primary deficit was almost down to zero. ${ }^{26}$

\footnotetext{
${ }^{18}$ Gulahati and Nallari (1990); Selvon (2005).

${ }^{19}$ 23-30\% (depending on the measure) in 1979 and almost as much again in 1981. Ancharaz (2004, p.6), Brautigam (1999b, 156-157), Gulahati and Nallari (1990); Iman and Manoiu (2008).

${ }^{20}$ Ancharaz (2004).

${ }^{21}$ Brautigam (1999b, pp. 156-157) and Subramanian (2001).

${ }^{22}$ Ancharez (2008), Iman and Manoiu (2008), and Subramanian (2010, p.10-12).

23 "When we came to power in 2005, the situation was awful." -- Rama Sithanen, Finance Minister (Labor Party), in "Economy: A Lesson in Reinvention,” by Tony Hawkins, Financial Times, March 11, 2008.

${ }^{24}$ Needless to say, most countries are less welcoming to immigrants. Think of South African attacks on recent Mozambiquan and Zimbabwean immigrants in 2008, Ivoirian attacks on its immigrants in 2002, or Uganda booting out its entire Indian population in 1972.

${ }^{25}$ The Business Facilitation Act evidently succeeded in boosting the climate for business in Mauritius as judged by the Doing Business Report of the World Bank and the Global Competitiveness measure from the
} 
The government had achieved enough reduction in the budget deficit, and had enough foresight when the US sub-prime mortgage crisis lingered a year after its origins in mid-2007, to ease a bit fiscally as early as mid 2008, just in time for the global recession. ${ }^{27}$ This sort of example of desirable counter-cyclical fiscal policy - allowing deficits to fall in booms and rise in downturns -- had been rare among developing countries in the past, but was newly achieved by some in 2008-09.

With the loss of MFN preferences for clothing exports, and the new competition from China in all manufactures, Mauritians described the way forward as "the 3rd sector," that is, services. Tourism was already the leading service export, and was now joined by banking and ICT, looking to Singapore as a model. (Join the club!)

Is the move to banking a wishful-thinking pursuit of a mirage in the desert? Not quite. But neither should the island see itself as the next Singapore. Subramanian explains: "the offshore financial sector has grown because of the Indian diaspora which led to the signing of a double taxation treaty between Mauritius and India. As a result, Mauritian offshore centres have mediated large financial flows to India and Mauritius has become the largest investor in India.” If the financial center is built on Indians using a bilateral investment treaty for round-tripping, it is unlikely to be durable.

More recent plans call for expansion in a variety of other sectors: a seafood hub, an "integrated resorts" scheme, and more. They are characterized as "pillars" of the new economy. ${ }^{28}$

Even within the textiles and apparel sector, when a country loses low-end exports to low-wage competition, a reduced subset of the industry can be reborn through innovation. This describes northern Italy, for example, and it also describes Mauritius. Subramanian (2010, p. 17) : "the observation that exports in the EPZ have picked up in 2006 even though employment has continued to decline suggests that the textile and clothing sector in Mauritius is consolidating itself through investment in capital-intensive spinning (and weaving) activities aimed at better integration of the supply chain, this with a view to improving response to clients."

One can see tangible evidence of precisely such adaptation if one visits the successful Compagnie Mauricienne de Textiles. Rather than closing its clothing factory when the MFA ended, the company brought in an experienced new manager from India, opened a textile factory just across the parking lot, adopted current Asian technology, and

World Economic Forum (especially low barriers to trading across borders, such as days required for importing and exporting).

${ }^{26}$ Down from $1 \frac{1}{2} \%$ of GDP in 2005/06. For example, subsidies on rice and flour were removed. African Economic Outlook (2008, p. 434).

${ }^{27}$ Ministry of Finance (2008).

${ }^{28}$ When one hears of the sectors that have been designated as promising priorities for the future, it is difficult to discern the balance of government versus private participation in these plans. The government intervenes in many markets. (Lange, 2009, declares Mauritius a "developmental state" - for which he credits direct British colonial rule!) The strategic documents describing "pillars" are from the government; but officials deny that they are directing investment in the manner of socialist 5-year plans. Perhaps the "administrative guidance" of some East Asian countries is a parallel. Perhaps, in a sufficiently small country, a meeting to plan an integrated resort (a luxury hotel and villa development intended to attract foreign investors), even though it is called by government officials, need not operate fundamentally differently from the sort of meeting among private developers that would take place in a larger more purely capitalist country. 
is now fully integrated. ${ }^{29}$ On one side of the parking lot, the textile plant is so highly automated that it requires only a few young workers, who get around the large building on roller skates to tend the machines. Meanwhile, the apparel plant next door is still a beehive of low-skilled workers. The textile factory takes raw cotton and turns it into yarn, and fabric. The apparel factory takes the fabric and turns it into finished garments. Although the integrated process can be run continuously from beginning to end, CMT also keeps inventories of many kinds of cloth, so as to be able to respond even more rapidly to the sort of sudden new requests that are standard in the world of fashion.

One plausible way forward for Mauritius is as a platform for firms from India and China wishing to do business in Africa. Everyone's favorite entrepot, Singapore, is an obvous model. (Mauritius has the second biggest container cargo in sub-Saharan Africa). But another possible model is Hong Kong, which long had a favored position as the window or platform for investing into China. Another possible analogy more recent in origin is Dubai, which can be viewed as the platform for investing into the volatile Middle East. These city states share the traits of being open, stable, well-functioning, cosmopolitan, and adaptable. ${ }^{30}$

\section{Economists' Hypotheses Regarding Mauritian Economic Performance}

We review six explanations that have been put forward for the success of Mauritius. (This section owes much to the cataloging of theories in Subramanian, 2007. ${ }^{31}$ ) Each of these explanations will be rejected at least in part, suggesting that the field is still open.

\section{Initial conditions}

After the fact, success often looks pre-ordained. Any recounting of the performance of the pearl of the Indian Ocean must start by relating how two Nobel Prize winners, around the time of independence, independently forecast doom instead of success. The first, James Meade (1961), was later to win the Nobel Prize in Economics: "Heavy population pressure must inevitably reduce real income per head...That surely is bad enough in a community that is full of political conflict...the outlook for peaceful development is poor.” The second, V.S. Naipaul (1972), had a more literary vantage point, but came to the same conclusion: "The disaster has occurred... now given a thing

\footnotetext{
${ }^{29}$ The primary motivation for integrated production was the African Growth and Opportunity Act (AGOA), under which the United States decided in 2000 to grant duty-free access to African apparel exports provided that the fabric or yarn not be imported from Europe, but rather be either home-made or imported from the United States. Mauritius was one of the first two countries [with Kenya] to be approved for AGOA, which has proven successful (Frazer and Van Biesebroeck, 2010, P.130) to a surprising extent. The AGOA benefits are no longer relevant, but once established, CMT's integrated production is profitable regardless. (The manager told us that he knew this ahead of time, but that the owners who hired him did not.)

${ }^{30}$ China has already begun to use Mauritius as a platform for investment into Africa. Ancharez (2008, pp. $6,19)$.

${ }^{31}$ Also Brautigam (1997a, b), Alec Russell “An Island Bridging Africa and Asia,” Financial Times, March 11,2008 , and others.
} 
called independence and set adrift, an abandoned imperial barracoon, incapable of economic or cultural autonomy..."

There were excellent reasons for such fears. Three were perhaps uppermost in the minds of observers at the time; three more would have been particularly worrisome given empirical regularities that we know about today.

- Geography: A country that is small lacks internal economies of scale and a complete array of endowments. Many small countries make up for these limitations through international trade. But a country that is located remotely from the centers of population and economic activity is at a disadvantage for trade. Mauritius ranks as more disadvantaged than Madagascar, and alongside 11 South Pacific countries, as the most remote in the world. ${ }^{32}$

- Ethnic tensions. Mauritius had, and has, a split of several major ethnic groups that would normally be considered unconducive to growth. Social scientists generally consider a low degree of ethnic fragmentation to be the best for growth (Sweden, Japan, Botswana). ${ }^{33}$ A widely used measure of ethnic, linguistic, and religious fragmentation shows Mauritius as far more split than all the other small African island states, and remarkably similar to Trinidad and Tobago, and Fiji. ${ }^{34}$ As we saw in the preceding section, ethnic riots accompanied the run-up to independence.

- Population density. The island has one of the higher ratios of population to land area in the world. Unemployment was high in the 1960s, resulting in out-migration. The apparent overpopulation, together with ethnic and political conflict, were major reasons for the pessimism of Meade and Naipaul.

- Volatile monocrop. The economy of 1968 was considered highly dependent on a single crop, sugar, that suffers from high volatility. Today, even more than then, we are aware of the Natural Resource Curse. It is discussed in the next sub-section.

- Regression to the mean. The growth literature suggests that, although there is no tendency for countries' income levels to converge unconditionally, there is a significant tendency for gradual conditional convergence. That is, if various factors such as geographical suitability for trade suggest an income level above where a country is at the beginning of a sample period, on average its income can be expected

${ }^{32}$ Remoteness is measured as a weighted average of log distance from other countries, with shares of either GDP or population used as weights.

${ }^{33}$ Easterly and Levine (1997). One hypothesis is that the relationship is U-shaped, that a very high degree of fragmentation can also be fine for growth (20 small groups, none of which dominate), and that it is the middle degree that is dangerous. Collier and Bates (2008, 393-395), Bates and Yackolev (2002) and Collier (2000). They give Botswana as their example of an ethnically homogeneous country and Tanzania as an example at the other extreme. Carroll and Carroll (1997, p. 465) consider Botswana to be ethnically divided because, even though $80 \%$ of the population is Tswana, they come from eight Tswana tribes; perhaps, then, the distinction between very high and very low ethnic fragmentation is a subtle matter of definition. [This paper was brought to my attention by Prime Minister Navin Ramgoolam.]

${ }^{34}$ The remarkable part is that all three tropical islands, though located in three different oceans, got their ethnic diversity in essentially the same way: Indians were brought to work the sugar fields. Trinidad and Tobago subsequently enjoyed oil wealth, but suffered the natural resource curses of rent-seeking behavior and Dutch Disease cycles in a way that Mauritius has been able to avoid by using rents from trade privileges effectively (Auty, 2009, p. 2-3). Trinidad and Tobago fits right on the international Natural Resource Curse line: 1970-2008 growth was a little sub-standard, in a way that can be statistically associated with the high share of oil in its exports (Frankel, 2010, Figure 1). Fiji is discussed toward the end of this paper. 
to move slowly in the direction of that long-run equilibrium. But Mauritius in the 1960s had an income level above the Africa average, and perhaps above what would be predicted from its geography. What had been a favorable location a century earlier - a deepwater port well-placed for stopping off on the shipping route to India had become unfavorable when the Suez Canal opened in 1869. Looking forward from the 1960s, one might have predicted downward convergence.

- Last on the list of poor initial conditions at the time of independence were

distortionary trade barriers. It is not that the first government was especially antimarket in philosophy. But import substitution was the fashion of the day. Today it is more widely believed that trade is good for economic performance, less because classical and modern trade theory say so, perhaps, than because of the demonstration of trade-led growth in East Asia and elsewhere.

All in all, one must agree with Meade that the initial conditions were not auspicious.

\section{Sugar wealth}

The second possible explanation for the success of Mauritius is the sugar plantations.

But natural resources often have undesirable effects. ${ }^{35}$ For every Botswana, a diamond-rich and successful state, there is at least one Congo, a mineral-rich and failed state. Indeed, as already noted, dependence on a volatile monocrop economy is on the list of poor initial conditions facing Mauritius at the time of independence. There are many versions of the Natural Resource Curse. Perhaps a majority focus on mineral commodities as the culprit, or more specifically oil; some of these explicitly exclude agricultural products. ${ }^{36}$

But there is a version of the Natural Resource Curse, designed by Engerman and Sokoloff (1997, 2000, 2002) to think about the Americas (Brazil versus the United States), that explicitly includes sugar. The idea is that lands endowed with point-source extractive industries (oil and mining) and plantation crops (sugar and cotton) developed institutions of slavery, inequality, dictatorship, and state control, whereas those climates suited to fishing and small farms (fruits and vegetables, grain and livestock) developed institutions based on individualism, democracy, egalitarianism, and capitalism. When the industrial revolution came along, the latter areas were well-suited to make the most of it. Those that had specialized in extractive industries were not, because society had come to depend on class structure and authoritarianism, rather than on individual incentive and decentralized decision-making.

Several other versions of the Natural Resource Curse apply to agriculture products in general as much as to minerals: external returns to manufacturing, the Dutch Disease, and commodity volatility.

\footnotetext{
${ }^{35}$ Frankel (2010) offers a survey of the Natural Resource Curse.

${ }^{36}$ Sala-I-Martin and Subramanian (2003), Bulte, Damania, and Deacon (2005), and Mehlum, Moene and Torvik (2006). The latter use the phrase "lootable" resources. Isham, et al, (2005) explicitly include coffee and cocoa as plantation crops that are damaging to institutional development, alongside oil and other point-source minerals, rather than as small-scale farm products. [But in Africa cocoa and coffee should perhaps count as small-scale farming.]
} 
Outside of classical economics, diversification out of primary commodities into manufacturing in most circles is considered self-evidently desirable. Several dubious arguments have been made for it. One is the "structuralist" or Prebisch-Singer hypothesis of secularly declining commodity prices, which is not generally borne out by the long-term data. Another is the mistaken "cargo cult" inference -- based on the observation that advanced countries have heavy industries like steel mills -- that these visible monuments are necessarily the route to economic development. But one should not dismiss more valid considerations, just because less valid arguments for diversification into manufacturing are sometimes made.

Is industrialization the sine qua non of economic development? Is encouragement of manufacturing necessary to achieve high income? Classical economic theory says "no:" countries are best off producing whatever is their comparative advantage, whether that is natural resources or manufacturing. In this $19^{\text {th }}$ century view, attempts by Brazil to industrialize were as foolish as it would have been for Great Britain to try to grow coffee and oranges in hothouses. But the structuralists were never alone in their feeling that countries only get sustainably rich if they industrialize. Nor were they ever alone in feeling that industrialization in turn requires an extra push from the government (at least for latecomers), often known as industrial policy.

Matsuyama (1992) provided an influential model formalizing this intuition: the manufacturing sector is assumed to be characterized by learning by doing, while the agricultural sector is not. The implication is that deliberate policy-induced diversification out of primary products into manufacturing is justified, and that a permanent commodity boom that crowds out manufacturing can indeed be harmful.

On the other side, it must be pointed out that there is no reason why learning by doing should be the exclusive preserve of manufacturing tradables. Nontradables can enjoy learning by doing. ${ }^{37}$ Mineral and agricultural sectors can as well. Some countries have experienced tremendous productivity growth in the primary sector. American productivity gains have been aided by public investment since the late $19^{\text {th }}$ century. ${ }^{38}$ Attempts by governments in developing countries to force linkages between the primary sector and processing industries, however, have been less successful. ${ }^{39}$

Some have suggested that the high volatility that afflicts most commodities is the source of the natural resource curse. ${ }^{40}$ Highly variable prices on world markets, usually attributable to low short-run elasticities, are the most obvious sort of volatility experienced by agricultural and mineral products. But there are other sorts as well, both on the demand side and the supply side. On the demand side, large swings in the trade policies of the major markets for Mauritian sugar have been a bigger source of volatility during its history than the variance in a world price of sugar. On the supply side, cyclones have caused great damage to the crop, particularly several that hit in the 1960s.

\footnotetext{
${ }^{37}$ Torvik (2001).

${ }^{38}$ In such knowledge infrastructure institutions as the U.S. Geological Survey, the Agricultural Extension program, and Land-Grant Colleges. Wright and Czelusta (2006).

39 Hausmann, Klinger and Lawrence (2008) warn of the pitfalls of assuming that South Africa, for example, can move from diamond mining to diamond cutting. They are not opposed to industrial policy, but rather believe that linkages are more likely where factor intensities and technological requirements are similar across sectors, rather than to upstream or downstream industries.

${ }^{40}$ Blattman, Hwang, and Williamson (2007), Hausmann and Rigobon (2003) and Poelhekke and van der Ploeg (2007).
} 
Over the 150 years during which Mauritius was overwhelmingly a sugar economy, it suffered from periodic Dutch Disease cycles due to big changes in European barriers/preferences toward its crop. Three booms related to the granting of preferences occurred in the 1830s, 1919-20, and 1973-74. Ancharaz (p.5) sees in these Mauritian booms the familiar Dutch Disease pattern of a rise in public spending “of dubious economic value,” budget deficits, inflation (especially in the price of land), and real appreciation of the currency.

Even leaving aside undesirable macroeconomic effects of commodity booms, cyclical shifts of resources (labor, capital and land) back and forth across sectors may incur needless transaction costs. Frictional unemployment of labor, incomplete utilization of the capital stock, and incomplete occupancy of housing are true deadweight costs, even if they are temporary. A diversified country is indeed probably better off than one specialized in oil or a few other commodities, other things equal.

\section{Openness}

Subramanian (2009) attributes to Jeff Sachs ${ }^{41}$ the view that an open trade policy contributed to Mauritian success, and then rejects it:

Mauritius was one of the countries that Sachs and Warner classified as being open or following liberal trade policies. But this categorization of Mauritius as an open economy was misleading, even incorrect. In Subramanian and Roy (2003: tables 4 and 5), we provide estimates of the restrictiveness of Mauritius' trade policy regime. During the 1970s and 1980s, Mauritius remained a highly protected economy: the average rate of protection was high and dispersed. In 1980, the average effective protection exceeded 100 per cent, and although this diminished by the end of the 1980s, it was still very high (65 per cent). Moreover until the 1980s, there were also extensive quantitative restrictions in the form of import licensing, covering nearly 60 per cent of imports.

That Mauritius did not follow free trade policies, at least until relatively recently, does not mean that trade was not a critical part of the story. It seems difficult to escape the conclusion that it was. Exports and imports are each about 2/3 of GDP. But Subramanian and Roy (2003) and Subramanian $(2001,2009)$ discuss two other particular trade-related hypotheses, to which we now turn.

\section{Export Processing Zone and Heterodox Trade Strategy}

"Free trade" is normally taken to mean laissez faire, the absence of trade distorting policies, whether anti-import (tariff or non-tariff barriers against imports) or pro-export (export subsidies and other export-promoting policies, including privileged access to imported inputs). ${ }^{42}$ But Rodrik (1997) has suggested that Mauritius' success was the result of a "heterodox" trade policy reminiscent of the East Asian tigers, a strategy that created high returns to the export sector, while preventing resources from being diverted

\footnotetext{
${ }^{41}$ Sachs and Warner (1997).

${ }^{42}$ To the mercantilist-minded, import tariffs and export subsidies seem similarly designed: to increase the trade balance. To a trade theorist, the trade balance is determined in other ways in general equilibrium (national saving and investment) and in the very long run is zero; as a result, import tariffs lead to a lower level of overall trade (exports as well as imports) and export subsidies to a higher level (again, on both sides of the trade balance).
} 
into the protected import-competing sector. The specific institutional mechanism was the Export Processing Zone (EPZ), which was established in 1970.

It accomplished the successful promotion of exports by (i) giving EPZ firms tax advantages, (ii) eliminating tariffs on the imported inputs used by manufacturers, and (iii) setting laxer labor standards for EPZ workers and a lower minimum wage. Initially the differential between sugar workers and EPZ workers was almost 50\%. That the EPZ factory workers were mostly women made discriminatory labor laws politically possible.

Although there is a strong a priori case that the development of a manufacturing sector inside the EPZ was an important component of Mauritian success, there are two counterarguments to Rodrik and his heterodox trade policy. First, many countries, including a number in Africa, have established Export Processing Zones, without similarly successful results. ${ }^{43}$ Second, Subramanian and Roy (2003) compute that the various effective EPZ subsidies in Mauritius (encouraging resources to move into trade) were substantially smaller than subsidies to import-competing sectors (discouraging resources from moving into trade):

"[E]ffective protection for the import-competing sector averaged about 125 percent in the 1980s and about 65 per cent in the 1990s...Even allowing for favourable tax breaks, it seems that heterodox opening and intervention (in the form of subsidies in the export sector) did not offset completely the anti-export bias of the restrictive import regime.”

\section{Ideas and FDI}

Paul Romer $(1990,1993)$ contributed an approach to growth theory based on ideas (innovations in either products or production methods) as the key ingredient for development, rather than capital, labor, or other factors of production. Romer (1992) argues that importing ideas from abroad, through inward FDI, is an effective alternative to growing them at home. Specifically in the case of Mauritius, Chinese businessmen brought the idea of textile and apparel manufacturing to the EPZ, jump-starting the country's industrialization. ${ }^{44}$

Subramanian and Roy (2003) and Subramanian (2001; 2009, p.14) argue against Romer's explanation for Mauritian success, on the grounds that the share of foreign companies in the EPZ was not all that large: "For example, in 1984, only 12 per cent of the total employment in the EPZ was accounted for by wholly foreign-owned operations compared with 72, 42, and 64 per cent, respectively, in Korea, the Philippines and Malaysia. It is estimated that about 50 per cent of the total equity of firms in the EPZ was owned by Mauritian nationals." This criticism seems a trifle unfair. The idea of "ideas" is that they can be emulated, when observed at close hand. So it is perfectly plausible that local firms caught on quickly after the Chinese-owned apparel factories were successful. Hausmann and Rodrik (2003) would call it the social benefits of selfdiscovery.

A more serious objection is that the idea of producing clothing is rather obvious - it is famously the first rung on the ladder of industrialization (though, in fairness, this might not have been so obvious in 1970) - and that something else beyond FDI and the EPZ is

\footnotetext{
${ }^{43}$ Subramanian (2009): “Apart from Mauritius, EPZ facilities and the attendant incentives were provided by a host of other African countries such as Zimbabwe, Senegal, Madagascar and Cameroon.... The EPZ experiment failed in almost all these countries."

44 Also Nath and Madhoo (2004) and Ancharez (2008).
} 
needed to explain why it worked in Mauritius and not in other African countries. For Subramanian (2009) a key ingredient is preferential treatment for Mauritian exports in the markets of Europe and the United States. I agree that this was a sine qua non. Under the Multi-Fiber Agreement (MFA) exports of textile and apparel were limited by quotas, but Mauritius benefited from relatively lenient treatment. ${ }^{45}$ That Hong Kong had quickly used up its export quotas, and had proceeded to fill the quotas in other Asian countries, explains why its businessmen were willing to start apparel factories in such a far-off country as Mauritius, which had not been using its quota.

Three more ingredients were useful. A key one was a competitively valued exchange rate, ${ }^{46}$ which helped offset the anti-trade bias of the import tariffs. Another was ethnic links between the Chinese and Chinese-Mauritians whose ancestors had immigrated long before. $^{47}$ Chinese-Mauritians had been instrumental in persuading the government to set up the EPZ in the first place. ${ }^{48}$ Another ingredient was the capital of the Franco-Mauritians, some of whom set up factories in parallel with the Chinese. ${ }^{49}$

\section{Good institutions}

After poking holes in all the other hypotheses -- initial conditions, open trade policies, a heterodox trade policy built around the Export Processing Zone, and the importation of manufacturing ideas via Foreign Direct Investment -- Subramanian (2009) declares himself for institutions as the explanation. It was good institutions that allowed Mauritius to develop the EPZ effectively, where others might have gotten mired down in corruption. He points out that Mauritius ranks high in the standard measures of the quality of institutions: political participation, rule of law, and control of corruption. As many have noted, Mauritius and Botswana, two star performers, are also the only two African countries to have been democratic continuously since independence. ${ }^{50}$

A prominent trend in thinking regarding economic development is that the quality of institutions, especially property rights and the rule of law, is the fundamental factor that determines which countries experience good performance and which do not, ${ }^{51}$ and that it is futile to recommend good macroeconomic or microeconomic policies if the institutional structure is not there to support them. ${ }^{52}$ Acemoglu, Johnson, and Robinson

\footnotetext{
45 It could be argued that the US also gave favorable treatment to the exports of Korea and Taiwan during the Cold War. when two countries share some population that speaks the same language (perhaps especially so if the language is Chinese). Frankel (1997, pp.74-75, 104).

48 Subramanian (2001). Particularly one E. Lim Fat (Brautigam 1999b, p. 148). The government sent a team to Hong Kong and Taiwan to investigate the export success of these newborn tigers, and the EPZ Act of 1970 was the result of its recommendations.

49 Brautigam (1999b, p. 149) reports that from the beginning, half of the EPZ investment came from the locals.

50 E.g., Carroll and Carroll (1991). Radelet (2010) argues that progress toward democracy has contributed importantly to economic progress among a number of African countries. [Anckar (2008) finds that small countries are no more likely to be democracies than large ones.]

51 North (1994). Four of the most important empirical contributions are Barro (1991), Hall and Jones (1999), Acemoglu, Johnson, and Robinson (2001), and Rodrik, Subramanian, and Trebbi (2003).

52 Acemoglu, Johnson, Robinson, and Thaicharoen (2003).
} 
(2001) famously use settler mortality rates as an instrumental variable for institutions. Nath and Neti (2008) suggest that the settler story applies literally to Mauritius: success is attributed to good institutions, which is attributed to European settlement, and in turn to suitable climate.

\section{Digging Deeper}

\section{Deeper determinants}

Perhaps the most interesting part of the debate on growth over the past decade has been: what are the deeper determinants? Yes, policies regarding taxes, government spending, tariffs help determine investment, education and trade, which in turn are good for growth. But what are the deeper determinants of those policies? Rodrik, Subramanian and Trebbi (2004) pose the question well. In their view, there are three emerging theories: (i) openness, (ii) geography -- which I prefer to interpret more narrowly as tropical disease -- and (iii) institutions. Each theory can be captured by some standard measures, such as trade volume, malaria incidence, and rule of law, respectively. Each has serious endogeneity problems that must be addressed: when countries grow richer they lower tariffs, drain swamps, and adopt accounting standards. The endogeneity of trade has been largely addressed by geographic determinants such as access to coastline. It ought to be possible to address malaria by purely topographic and climatologic determinants.

That leaves institutions. The settler mortality variable of Acemoglu et al (1999) is probably the best we have econometrically. But it is just a start on the problem. The very aspects that make it exogenous - colonial history and geographic susceptibility to disease -also raise the question whether the sort of institutions at stake are so predetermined as to make post-independence mortals powerless to shape them so as to benefit their countries. ${ }^{53}$ But fatalist determinism can't be the answer. Good institutions have been chosen by mortal people in living memory, in countries as diverse as Germany, Singapore, Hong Kong, Chile, Botswana... and Mauritius.

\section{Measuring institutions}

We will use measures of institutions in the econometric analysis in the next section. But some are vulnerable to subjectivity. Where they come from surveys (for example Transparency International's widely cited results on corruption), there is the danger of a "halo effect." Survey respondents "know" that Switzerland is a more successful country than Colombia, and so they tend to give higher ratings to institutions in one place than the other, even when it might not be based on specific familiarity with the facts. Rotberg and Gisselquist (2009) have since 2007 compiled The Index of African Governance which attempts to be less subjective than survey-based measures from Transparency

\footnotetext{
53 One might argue that the same is true of trade, as have Rodriguez and Rodrik (2001) in critiquing Frankel and Romer (1999). They ask how we can be sure that the beneficial effects of trade that result from trade policy decisions are similar to the beneficial effects of trade that are observed to result from sea access and other geographic variables. The answer is that, although, as always with instrumental variables, we cannot be sure the effects are the same, (i) those anti-globalizers who question the benefits of trade liberalization generally feel the same when it is technological progress in transport and communications that shrinks the world, and (ii) it is possible to measure trade unambiguously. The concept of "better or worse institutions" lacks the unambiguous unidirectionality of "more or less trade."
} 
International or the World Governance Indicators (WGI). The cost of eliminating subjectivity is increased reliance on measures that could be regarded as endogenous outcomes, instead of the more exogenous institutions that most of us mean by the word "governance." The Index of African Governance data are good for the ranking game, but perhaps more worrisome as the independent variable in a regression. The solution is to drop the three categories of "outcome” components (economic opportunity, safety/security, and health/human development), and focus solely on the two "input" sets of components (rule of law and participation/human rights). The correlation between the rule of law measures in the WGI and in African Governance is .91.

Mauritius ranks first by participation and human rights. It ranks third in rule of law, after Cape Verde and Botswana. Amazingly, the Heritage Foundation in 2011 ranked the island country's economic freedom, not just as first in Africa, but as number eight in the world. Transparency International and the Internet Center for Corruption Research place Mauritius second only to Botswana in freedom from corruption within the region. ${ }^{54}$

It can be hard to square such rankings with common reports from citizens of government corruption that recurrently goes unpunished. ${ }^{55}$ Perhaps it is best to conclude that the basic comparison to most other African countries is valid, but Mauritius still does not belong with the Nordic countries. For perspective, when Transparency International gives Mauritius a ranking of number 46 in its Corruptions Perspectives index for 2011, that is midway between New Zealand's \#1 and Liberia, Trinidad, or Zambia, which are tied for \#91. Its raw score (5.1) is midway between the United States (7.1) and the threeway tie of Albania, India and Swaziland (3.1, ranked \#95).

Very few available indicators of the quality of institutions seem able to escape both the Scylla of subjectivity in judgments and the Charybdis of judging by outcomes. To measure fundamental institutional quality, two of the best candidates from the Index of African Governance are the reported number of days to settle a contract dispute and the number of pre-trial detainees. Mauritius does not rank as highly if judged by these two statistics as by the other indicators. Does the island paradise thus benefit from a discriminatory halo effect when its institutions are rated? National prison authorities themselves are the sources for the raw detainee data; perhaps the researchers are not able to enforce across countries adequate honesty in self-reporting. We are left short of unambiguous indications of high-quality institutions.

The unusual arrangement whereby the British Privy Council serves as the Supreme Court of Mauritius sounds like a textbook case of a well-designed institution: It can be expected to deliver answers that will be respected by competing groups who would not necessarily trust home-grown mechanisms. Another observation encourages the notion that Mauritius does actually have effective institutions: A sophisticated cyclone warning system successfully gives warning of coming cyclones on a scale of four alerts, allowing the people to move to higher ground. The system requires both government competence and public cooperation. A new tsunami warning center has also been described as state of the art. These are perhaps clean examples of specific good institutions.

\footnotetext{
${ }^{54}$ Rotberg and Gisselquist (2009).

55 Dukhira (2002, 279-282) and Selvon (2005, 492-494). Crime is another area where local residents (Dukhira, 2002, 271-276; and Selvon, 2005) paint a less idyllic picture than the rankings, which give Mauritius the best possible rating on violent crime (homicides) -- Rotberg and Gisselquist (2009 p. 57, 90).
} 


\section{Democracy}

As noted, Mauritius and Botswana are the two African countries that have been continuously democratic from birth.

The statistical evidence across countries is at best mixed as to whether democracy per se is good for economic performance. Barro (1996) finds that it is the rule of law, free markets, education, and low government consumption that are good for growth, not democracy per se. Tavares and Wacziarg (2001) find that it is education, not democracy per se. Alesina, et al, (1996) find that it is political stability, not democracy per se, that is good for growth. ${ }^{56}$ Some even find that, after controlling for important factors such as the rule of law and political stability, democracy has if anything a weak negative effect on growth. ${ }^{57}$

One can claim good evidence for the reverse causation, that economic growth leads to democracy, often assisted by the creation of a middle class. ${ }^{58}$ Examples include Korea and Taiwan. Of course democracy is normally regarded as an end in itself, aside from whether it promotes economic growth. Even here, one must note that the benefits of the formalities of elections can be over-emphasized. For one thing, elections can be a sham. Such leaders as Robert Mugabe, Hamid Karzai, and George W. Bush have each claimed to have been elected without having in fact earned more votes than their opponents. Western style or one-man one-vote elections should perhaps receive less priority in developing countries than the fundamental principles of rule of law, human rights, freedom of expression, economic freedom, minority rights, and some form of popular representation. ${ }^{59}$

\section{The Econometrics}

Econometric studies of economic performance worldwide often show a negative dummy variable for Africa. We begin with some econometrics that includes other parts of the world, so as to see to what extent Africa's problems stem from variables such as tropical location. But rather than repeating the sort of 150-country data sets that are so familiar from other papers, we look at a cross-section consisting of island countries around the world. There are at least two reasons why this is of interest. First, islands are a test case that can isolate certain factors. ${ }^{60}$ For example, national borders are not likely to be endogenous. Second, as noted, not just Mauritius, but three out of the top four performers in Africa are islands, an intriguing fact that invites investigation.

\footnotetext{
${ }^{56}$ It is worth noting, however, that many autocracies fail to deliver political stability that survives the term or life of a particular autocrat (leaving aside whether they deliver economic benefits for the people). China is the exception; also Singapore if it is not counted as a democracy.

${ }^{57}$ Collier and Hoeffler (2009) find that when developing countries have democracies, as opposed to advanced country democracies, they tend to feature weak checks and balances. As a result, when developing countries also have high natural resource rents the result is on average bad for economic growth.

${ }_{58}$ Helliwell (1994), Huber, Rueschemeyer and Stephens (1993), Lipset (1994) and Minier (1998).

59 Zakaria (1997, 2004).

${ }^{60}$ Feyrer and Sacerdote (2009) study a sample of islands as a natural experiment. (Their finding is that the length of the colonial period is an important determinant of income today).
} 


\section{Performance Across Island Countries}

Table 3 reports results of a pure cross-section of island countries. Our dependent variable is per capita income in 2006 (PPP basis). The results show a highly significant negative effect for a dummy variable that registers a country's location in the tropics. Since the variables are in log form, a coefficient of -1.8 means that non-tropical countries have a six-fold advantage relative to tropical countries, other things equal. ${ }^{61}$ The Africa dummy is negative, but not statistically significant when included along with the tropic dummy. The World Governance Indicators rule of law variable has a highly significant positive effect. $^{62}$ Its presence takes two-thirds off of the tropic dummy, confirming the view that tropical lands tend to develop less satisfactory institutions. ${ }^{63}$ Surprisingly, the coefficient on size (population) is negative. Normally size is a positive factor for income, presumably due to internal economies of scale and diversity of factor endowments. One conceivable explanation is that all islands are so geographically welldisposed to trade, because they by definition have good access to the sea, that they are able to use trade to make up for the disadvantages of small size.

Within the island data set the trade/GDP ratio has a highly significant positive effect. Remoteness has the expected negative sign but it is not significant when it has to compete with trade, the main channel through which it is thought to work. When, however, trade is excluded and we also condition on the WGI measure of rule of law, remoteness is indeed significant, while the effect of the tropic dummy is greatly reduced. Density too has the expected negative sign but is not statistically significant. Finally, we tried fragmentation and fragmentation squared, to test the hypothesis of a U-shaped relationship between ethnic/linguistic/religious homogeneity and economic success. They are not yet significant. By limiting the data set to islands we have reduced the sample size to 31, which inevitably raises standard errors, and may possibly explain the statistical insignificance of many of these variables (remoteness, density, fragmentation).

Table 4 allows for conditional convergence in the islands data set by including initial income as a regressor. The base case has only initial income and size. In Table 4a the initial year is 1968, the year of Mauritian independence. The coefficient on income is very close to 1 , so that we can think of the results as pertaining to average growth rates over the period. That the coefficient is so close to 1 may also indicate that we have not done a good job finding other determinants of equilibrium income. [When the initial year is 1968 and we have only 15 island observations, nothing else is significant. These results are in Appendix Table 4a. If we drop the trade and density variables then we can expand the sample size to 20.]

A limited specification estimated on 20 countries is enough to generate some significant results - at least when considering the non-base variables one by one. Remoteness is significant, with the hypothesized negative effect. Significant coefficients on fragmentation (negative) and fragmentation squared (positive) support the U-shaped hypothesis: The suggestion is that either complete homogeneity or high fragmentation

\footnotetext{
${ }^{61} \exp (-1.8)=.16$.

${ }^{62}$ When we tried other measures of institutions from Freedom House, they did not do as well, at least not when they had to compete with the WGI measure.

${ }^{63}$ E.g., Hall and Jones (1999) and Easterly and Levine (2002). The Acemoglu et al (2001) story about settler mortality is one way this could happen.
} 
can be good for growth, but that a modest number of large ethnic/linguistic groups is bad for growth.

When the initial year is 1976, we have 21 to 24 observations, in Table 4b. Trade and size both now show significant positive effects. (Density is of the hypothesized sign but insignificant.) The negative effect of remoteness is now statistically significant, except when it has to compete with the trade variable. (The explanation could be either multicollinearity or a difference in sample size.) The U-shaped fragmentation relationship is again significant.

When we start the data in 1996, in Table 4c, we are able to expand the sample size further and also to use the World Governance Indicator rule of law index. WGI is statistically significant, but trade loses much of its significant positive effect.

Remoteness becomes a significantly negative influence even when it has to compete with the trade variable. Fragmentation loses statistical significance.

\section{Performance Across African Countries}

Next we switch to a data set consisting of African countries. Here we can use the Index of African Governance, which attempts to avoid some of the subjectivity of the other measures of institutional quality. We add a dummy variable for the island countries. We also add a variable defined as the ratio of coastline to land area. This variable will be zero for a landlocked country, small for the Congo, larger for coastal countries, and larger still for small islands. The purpose is to test if access to the sea is the key variable or if something else special about small islands emerges.

We see in Table 5b that the coastal variable is positive and significant, but only when trade openness is not there to compete with it. A dummy variable for being landlocked is negative as expected, and significant, but again only when it does not have to compete with trade. (A country with at least a little sea access has an advantage of more than 50\% over one that is landlocked.) It seems clear that the coastal and landlocked variables have their effects via trade. The reader who is concerned about the endogeneity of trade will prefer the versions that show coastline and landlockedness in place of trade, as they are much more exogenous. Across the specifications, the coefficient on the island dummy hovers around zero.

Remoteness is never statistically significant [and is omitted from the results reported here.] One should not be too surprised that the remoteness variable does not work in the African context, even though it works well in the rest of the world. It uses straight line distances. Thus Tombuctou appears closer to Europe, and less remote, than does Accra, and Kisangani appears less remote than Maseru. These are not the right answers in a meaningful sense.

We add to the Africa regressions the measure of the rule of law from the Index of African Governance. It has a highly significant positive effect on income. The Freedom House measures of democracy do not do as well, though number of years under democracy (since independence) has a significant positive effect when it does not have to compete with Rule of Law. Population density has a significant negative effect. Size has no significant effect. 
Table 6 allows for conditional convergence in the Africa data set by including initial income per capita as a regressor. $\left[{ }^{64}\right]$ The coefficient on initial income is very high, indeed insignificantly less than one. Even if one takes the point estimate at face value (.8 in the sample that starts in 1968, the year of Mauritian independence), it says that income converges only $20 \%$ of the way to its long-run equilibrium over the span of 38 years. Most of the other variables are not significant, probably because of the small sample size. When the data sample starts in 1996, we raise the sample size to 41 . Now size has the expected positive sign, and at moderate significance levels. The other coefficients are of the expected signs, but of low significance. Table 7 repeats conditional convergence across African countries, but with landlocked dummy now added back in.

\section{Findings from the econometrics}

What have we learned from the regressions, across African countries or across island countries? There is some confirmation, in the island results that small size is a disadvantage but that trade can help make up for it (less so within Africa). Access to the sea is important. Landlocked African countries are at a disadvantage, as is well-known. ${ }^{65}$ But beyond sea access, there does not seem to anything special about islands per se. And straight-line distances are not very relevant in Africa, given that most trade has to go to a coastal port first.

Institutional measures make a big difference. Democratic institutions per se are not as important as rule of law. But institutions immediately bring up the question of endogeneity, as does trade. If trade and rule of law lead to good economics in Africa as elsewhere, but remoteness, tropics and fragmentation can't explain variation in trade, rule of law and incomes within Africa, what can explain relative performance within Africa? How did a small, remote, ethnically-divided country like Mauritius achieve success?

\section{So What is the Answer?}

Mauritian success really divides into two distinct accomplishments The first big accomplishment is that manufacturing took root after independence in 1968. The second is that the country was able to adjust relatively well to subsequent shocks, such as the oil price increases of the 1970s and further trade shocks in later decades, particularly the loss of sugar and textile preferences.

\section{Policies}

One can list many of the specific policies that led to these two achievements:

- Education. Mauritius has long invested heavily in quality schooling. Sir Ramgoolam boldly granted free education to all citizens. As a result, the country has achieved a high rate of literacy: $87 \%$ in 2007. Scholarships promote study abroad.

\footnotetext{
${ }^{64}$ Tables 6 and 7 and this paragraph might be omitted from a published version.

${ }^{65}$ Everything else equal, of course. Landlockedness hasn't stopped Botswana, nor has a long coastline mattered enough to save Somalia.
} 
Successful recycling of export rents contributed to the fiscal position that made all this investment in human capital possible.

- The Export Processing Zone. We have already noted the importance attributed to the decision to segment manufacturing exports from the rest of the economy by means of favorable tax policy and labor policy, and to encourage Foreign Direct Investment by Chinese businessmen to start the textile and apparel industry. ${ }^{66}$

- Favorable trade preferences from Britain, Europe and the United States. We have seen that the discrimination in favor of Mauritian exports in its major markets was more than enough to overcome what, at least at the beginning, was an anti-trade bias to national policy. Obviously these preferences were not policies set directly by Mauritians. Good luck must be given its due. This includes the good luck to have had multiple powerful patrons in the world, whether on geopolitical or sentimental grounds, going back to the time when the island was the strategic cross-roads of the East India trade. But Mauritian leaders were not merely passive beneficiaries in winning these trade preferences. Their diplomats worked actively to negotiate them.

- International diplomacy. When the UK joined the Common Market, the Commonwealth sugar preferences were replaced by the 1975 Sugar Protocol of the Lomé Convention. It happened that ACP sugar producers were negotiating terms for the access of their product at a time (1974) when world prices were very high. Most chose the option of relatively small EEC quotas, seduced by transitorily high world prices. But Mauritius negotiated a large quota at the domestic EEC price. Even though the EEC price was well below the world price then, during most of the time since it has been far above, due to the political power of European farmers domestically. Thus the decision by Mauritius to place priority on quantity turns out to have been a brilliant strategy. Sugar exports to Europe produced large rents for many years thereafter. ${ }^{67}$ The government was able to capture part of these rents and use the revenue for social spending. Another part of the rents went to investment. ${ }^{68}$ From the beginning Mauritian leaders took diplomatic steps to maintain good relationships with many countries, for example recognizing a single China very early.

- A competitive exchange rate. The IMF-recommended devaluations restored competitiveness in the early 1980s and put exports back on a vigorous footing. But Mauritius had a competitively valued currency during most of its history, compared with many African and Latin American countries. ${ }^{69}$ This, like the trade preferences, helped promote trade.

\section{Political institutions}

\footnotetext{
${ }^{66}$ Brautigam (1997a, b), Romer (1991), Subramanian (2001, 2007).

${ }^{67}$ Sugar rents were $5.4 \%$ of GDP on average, in some years much higher. Subramian (2001).

${ }^{68}$ Brautigam (1999b), Subramanian (2009).

${ }^{69}$ Iman and Manoiu (2008); African Economic Outlook (2008, p. 431).
} 
The question that previous authors have understandably had a harder time answering is why Mauritius made these good policy choices when so many other countries did not. To be sure, if we were to say that the country was lucky enough to have good leaders who made good decisions, that would not be an altogether discouraging moral. Such a conclusion might help to let modern policy-makers realize that they have free will, at times when they feel they are completely constrained by history and politics. But some other authors have tried to go further to explain institutional choices, and so should we.

Is it just luck that good decisions were made around the time of independence? If so, what accounts for the second half of Mauritian success, the ability to continue making relatively good decisions to adjust to the various shocks that came along in the 1970s and 2000s?

\section{Leadership}

An answer to the second question is that many of the good decisions that were made around the time of independence involved the setting up of institutions - or the adoption of practices that soon turned into institutions - and that these served the country well subsequently. ${ }^{70}$ The institutions were put in place primarily by a combination of the decolonizers and the first prime minister, Ramgoolam.

Brautigam (1999b, p. 144):

"Indeed, Mauritius was fortunate to have leaders who agreed to conduct their political competition within the boundaries of democratic rules and who saw early on that labor-intensive manufacturing for export could provide the employment required by the rapidly growing population. However once the "defining moment" of independence had passed, the rules of democracy and the other institutions established in that time created the constraints...for political action,...”

Or Brautigam (1999b, p. 158):

"Although the institutions put in place at the time of independence were established to solve the immediate problem of economic and political instability in an ethnically diverse land, they also created a set of norms, procedures, and constraints that continued to shape political and economic strategies and behavior in the post-independence decades...”

\section{The parliamentary system}

The rules and institutions that she has in mind concern first and foremost the Mauritian parliamentary system. During the preparations for independence, elites from different ethnic groups deadlocked over whether delegates should be elected by Proportional Representation. The British proposed pure Proportional Representation, but the Labour Party rejected it on grounds that it would fragment the political process too much. They wanted instead single-member districts which they would dominate. Other ethnic groups, naturally, wanted arrangements that would insure them more representation. The British brought in the 3-member Banwell Commission to work out a solution with the various parties in 1967. The system that resulted features 20 districts with three members each (and two additional from the small island of Rodriguez). The three candidates in each district to get the most votes are elected. But the electoral

\footnotetext{
${ }^{70}$ Acemoglu, Johnson and Robinson (2002) tell an analogous story for Botswana, attributing good policies to good institutions and then in turn tracing back the origins of the good institutions.
} 
commission can seat an additional eight of the unsuccessful candidates with the highest number of votes as "best losers," which works to insure representation by all minority groups. $^{71}$ Furthermore the boundaries of the districts were constructed to give bias to rural constituencies, which counteracts what Bates (1981) sees as a bias to urban constituencies in much of mainland Africa.

The need to form coalitions requires consensus-building, encourages inclusion (so that nobody seeks routes outside the system), and produces moderation in policy-making. Positions in the government have been shared out. Cabinet posts have been allocated to achieve ethnic balance. ${ }^{72}$ Various minorities have also been represented at other levels of public management. ${ }^{73}$

\section{No army}

Another institutional choice made at the beginning was to forego a standing army. As with Costa Rica, its neighbors (such as the Comoros) chose differently; and as with Costa Rica the "pacifist" route has paid off subsequently. Military spending in Mauritius in 1992 was only \$6 per capita, equal to 0.45 percent of GDP or 4 percent of spending on education and health. These statistics for other sub-Saharan countries are far higher, averaging \$20 per capita, 2.8 per cent of GDP, and 43 per cent of education and health spending. ${ }^{74}$ Brautigam points out the dual benefit to Mauritius: on the one hand, financial savings, and on the other hand freedom from the military coups that have plagued so many other African countries. One could argue that an island country has less need of an army than a mainland country ${ }^{75}$; but Cape Verde, the Seychelles and the Comoros all spend substantially higher percentages of GDP on defense.

\section{Institutions chosen around the time of independence.}

To summarize what we mean by institutions:

- No expropriation or taxing-away of the Franco-Mauritians' sugar plantations, which both allowed them to give up political power and established the importance of property rights.

- A politically, economically, and socially stable environment, with rule of law, respect for property rights, etc.

\footnotetext{
${ }^{71}$ Bowman (1991, 33-42), Brautigam (1999a, b p.146); Selvon (2005, p. 436); Subramanian (2009, fn 17). Some object to the best loser system because it perpetuates communalism. CUT: Ali Mansoor suggests that the system might have done better still if a few seats had been allotted for the top vote-getters in the whole island, unassociated either with geographic district or ethnic group. .

${ }^{72}$ Auty (2009a).

${ }^{73}$ The share of Muslims and Chinese in the Senior Public Service rose in the first three decades after independence. The share of Hindus had been a bit higher than in the general population ever since independence, but had not risen as of 1995 . The Chinese had $10 \%$ (vs. $2 \%$ of the population), the Creoles had $13 \%$ (vs. 28\% of the population), English/French have been reduced to zero, non-Muslim Indians steady at $68 \%$ (vs. $52 \%$ of the population), and Muslims $9 \%$ (vs. $17 \%$ of the population). Carroll and Carroll (1991, p. 476).

${ }^{74}$ Brautigam, p. 153. [Her source is HDR 1995 from UNDP.]

${ }^{75}$ Mauritius has in fact suffered the loss of territory to external military force. The United States and United Kingdom took the Chagos Islands in order to build the base of Diego Garcia, without the permission of either the islanders or Mauritius. Of course Mauritius has hardly been in a position to resist, with or without an army. But small size has not stopped other countries from futile military endeavors.
} 
- No single elite group was in a position to dominate the others.

- Vigorous political opposition and media.

- Parliamentary structure: coalition governments and comprehensive participation (representation for rural districts and ethnic minorities; best loser system; power sharing in cabinet)

- No army.

\section{The Deepest Determinants, and Lessons}

If good policies were not attributable solely to accidents of personalities or history, but also to good institutions that were put in place at independence, this just pushes the question back another step. When those institutions were put in place, was it attributable solely to accidents of personalities or history? If we dig deeper still can we find some more fundamental determinants as to why here and not somewhere else?

\section{Colonialists}

In many ways the British administrators in the end served the future nation well. It is relevant that very few British settlers arrived in the $19^{\text {th }}$ century to displace the Franco-Mauriciens, who remained in place as the land-owning elite. Thus when independence came, the British didn't have to protect the European settlers to the same extent as in Kenya or other countries. At the time of independence, they helped broker the power-sharing structure, in which the Franco-Mauriciens kept their sugar plantations, while surrendering political power.

It was also useful that the British took their time to prepare the colony for independence in a way that was not true of most African countries. That the process was drawn out to 1968 is to some extent attributable to the lack of enthusiasm for independence on the part of almost half the population.

\section{Cosmopolitanism}

Even though Mauritius ceased to be the cross-roads of the Indian Ocean when the Suez Canal opened, it retained its cosmopolitan character and mindset. This is another respect in which it resembles the entrepot city states, not just Singapore, but also Hong Kong and Dubai. This cosmopolitanism came in handy in the process of economic development. Ethnic links to China and India led directly to the rise of the textile and apparel sector and the financial center, respectively.

\section{Lessons for others}

There are at least three possible lessons that can be applied to the rest of Africa. First, trade is the key to growth, especially for a small country. Geographic impediments to trade can be counteracted in other ways, including a competitive exchange rate and regional free trade areas. Second, a well-designed electoral system can accommodate ethnic diversity -- even harness it for good. Although oppressive rule by a single group is not conducive to development, the opposite extreme of ethnically-blind democracy is not necessarily feasible in all countries. Deliberate steps to assure representation of each 
ethnic group might be necessary. Third, democracies can achieve economic reform, and perhaps in a more sustainable way than autocracies.

\section{The puzzle}

All this has been noted by other authors. But some ingredient seems to be missing. Something having to do with the intriguing puzzle noted at the beginning of the paper, that four of the most successful countries in Africa are islands. Some superior cultural values of the Indians? No. For one thing, while Mauritius was industrializing, India itself was stagnating with a miserable "Hindu rate of growth." Meanwhile, countries like Cape Verde have done well, with no Indians. ${ }^{76}$

\section{Immigrant isles}

What do Mauritius, Seychelles, and Cape Verde have in common? Each was uninhabited three centuries ago. ${ }^{77}$ Everyone who is there came from somewhere else, in modern times. The same is true of famously successful Singapore versus, for example, benighted Sri Lanka.

Why does it help if everyone is an immigrant? Two possible theories. One theory is that migrants self-select for vigor and initiative, and they pass these traits down to their descendants. Another theory is that most countries have nativist factions, children of the soil, who resent newcomers regardless of their merit or perhaps because of their merit. If everyone came from somewhere else, nobody can claim special privileges.

Consider a less successful small country that can serve as a comparator with Mauritius because they have some important things in common: Fiji. The tropical island economy has long been based on sugar, with indentured Indian workers brought to work the fields, and was supplemented more recently by tourism. Ethnic Indians became a majority of the Fijian population in the 1940s. ${ }^{78}$ But the first time an ethnic Indian was elected Prime Minister in 1999 (even though from a party that included many native Fijians), he was soon overthrown in a coup. The climate has been sufficiently bad for the Indians since then, that a high percentage of them have emigrated. As a result of the political instability and the loss of the Indians, the economy has done poorly. What was the key difference between Mauritius and Fiji? I believe it is that the native Fijians always resented the newcomers, whereas there were no native Mauritians (except the unfortunate dodo bird).

A combination of the two theories, immigrant initiative and absence of nativist resentment, would emphasize the benefits when everyone feels they have a common stake in building a new nation together.

Having said that, Mauritius illustrates that the ideal of an identity-blind meritocracy, however desirable ${ }^{79}$, is not essential. The important thing is for everyone to

\footnotetext{
${ }^{76} \mathrm{M}$ acedo and Pereira (2009) conclude that a combination of globalization and governance helps explain the success of Cape Verde, where emigrants' remittances are a maj or source of income.

${ }^{77}$ If we go back to 1493, then we can add São Tomé \& Príncipe to the list.

${ }^{78}$ Leuprecht (2009) makes much of the fact that, because the Indian migration occurred later in Fiji than in Mauritius, the population was younger and faster growing around the time of independence.

${ }^{79}$ Ali Mansoor points out that the nation building might have been even more successful if the "best loser" way of assuring minority representation had been supplemented by a provision for seating in parliament some top vote-getters who represented no ethnic group or geographic district, but instead the country as a whole.
} 
feel included. Some degree of power sharing along ethnic lines in some circumstances might help achieve this goal rather than hurt it. Another lesson for countries in Africa and elsewhere? History cannot be rewound. But any country can adopt policies that are inclusive to all its ethnic groups rather than exclusive and that are more welcoming to immigrants, past and future. This is perhaps the fourth of the lessons.

\section{Summary}

While tropicalness, remoteness, small size and landlockedness go a long way to explaining why Africa overall has done less well than some other regions economically, these variables do not help much to explain relative success within Africa (with the exception that access to the sea makes a difference). Tropicalness doesn't show up because almost all sub-Saharan countries share it. (The exceptions are South Africa, Lesotho and Swaziland.) Remoteness doesn't show up, if measured by straightline distances, because the problem of getting from the interior to the nearest seaport matters more in Africa than in most parts of the world. It is less clear why small African countries do not seem on average to suffer much the usual disadvantage relative to larger countries with economies of scale; it may reflect the success of several small countries, especially the three top-performing island countries -- Mauritius, Seychelles and Cape Verde - itself a puzzle considered by this paper.

Mauritius has made some wise policy decisions, including the establishment of the EPZ, diplomacy regarding trade preferences, spending on education, avoiding currency overvaluation, facilitation of business and so on. These policies can be attributed both to good deliberate choices of individuals and to good political institutions, particularly a parliamentary system that builds consensus by representing all groups. The good political institutions, in turn, were the outcome both of decisions made at the time of independence, by the first Prime Minister together with the outgoing colonial rulers, and of some still deeper underlying causes. Any country can in principle adopt good institutions and good policies at any time. But in the case of Mauritius, the deep underlying origins include a cosmopolitan population with an unusual combination of ethnicities: Franco-Mauritians and Creoles who were willing at the time of independence to trade off their past domination of political power for guarantees under the new system, Indians who were willing to take the other side of the bargain, and Chinese who had links to their country of origin. And, as with the Seychelles, Cape Verde, and São Tomé and Principe, everyone in Mauritius came from somewhere else.

\section{References}


Acemoglu, Daron, Simon Johnson, James Robinson, 2001, “Colonial Origins of Comparative

Development: An Empirical Investigation,” American Economic Review 91, 1369-1401.

Acemoglu, Daron, Simon Johnson, James Robinson, 2001, “An African Success Story: Botswana,” CEPR Discussion Paper No. 3219, February.

Acemoglu, Daron, Simon Johnson, James Robinson, and Yunyong Thaicharoen, 2003, "Institutional Causes, Macroeconomic Symptoms: Volatility, Crises and Growth," Journal of Monetary Economics (Elsevier), vol. 50(1), pages 49-123, January.

Alesina, Alberto, Sule Özler, Nouriel Roubini, and Phillip Swagel, 1996, "Political Instability and Economic Growth,” Journal of Economic Growth, Vol.1, No. 2, June.

Ancharaz, Vinaye dey, 2004, "The Effect of Trade Liberalization on Export-oriented Output and FDI: A Case Study of the Mauritian EPZ, 1971-1998,” University of Mauritius Research Journal, vol. 5 pp 1-30.

Ancharaz, Vinaye dey, 2008, “David V. Goliath: Mauritius Facing Up to China,” draft scoping study prepared for the African Economic Research Consortium, University of Mauritius, Réduit, January.

Anckar, Carsten, 2008, “Size, Islandness, and Democracy: A Global Comparison,” International Political Science Review, 29, no. 4, 433-459.

African Economic Outlook, 2008, "Mauritius," African Development Bank and Organisation for Economic Cooperation and Development.

Auty, Richard, 2009a, "Elites, Rent Cycling, and Development: Adjustment to Land Scarcity in Mauritius, Kenya and Cote d'Ivoire,” UNU/WIDER conference on Elites in Economic Development, Helsinki, June.

Auty, Richard, 2009b, “The Political Economy of Hydrocarbon Revenue Cycling in Trinidad and Tobago," paper prepared for workshop on Myths and Realities of Commodity Dependence: Policy Challenges and Opportunities for Latin America and the Caribbean, World Bank, Sept. 17-18, 2009.

Barro, Robert, 1991, "Economic Growth in a Cross Section of Countries,” Quarterly Journal of Economics, CVI, May, 407-444.

Bates, Robert, 1981, Markets and States in Tropical Africa (University of California Press: Berkeley).

Bates, Robert, and Irene Yackolev, 2002, "Ethnicity in Africa," in The Role of Social Capital in Development, edited by C. Grootaert and T. Van Bastelaer (Cambridge University Press: NY).

Blattman, Christopher, Jason Hwang, and Jeffrey Williamson, 2007, "Winners and Losers in the Commodity Lottery: The Impact of Terms of Trade Growth and Volatility in the Periphery 1870-1939," Journal of Development Economics (Elsevier), vol. 82(1), pages 156-179, January. NBER WP 10600.

Bowman, Larry W., 1991, Mauritius: Democracy and Development in the Indian Ocean (Westview Press Boulder, Colo.; Dartmouth: London ).

Brautigam, Deborah, 1997 a, "Institutions, Economic Reform, and Democratic Consolidation in Mauritius,” Comparative Politics, vol. 30, no. 1, October, pp 45-62.

Brautigam, Deborah, 1997 b, “The 'Mauritius Miracle’: Democracy, Institutions and Economic Policy,” in State, Conflict, and Democracy in Africa , edited by Richard Joseph (Lynee Riener: Boulder), 137-162.

Bulte, Erwin, Richard Damania, and Robert Deacon, 2005, "Resource Intensity, Institutions and Development,” World Development 33, no. 7, 1029-1044. 
Bunwaree, Sheila, and Roukaya Kadenally, 2006, Mauritius, Country Report based on Research and Dialogue with Political Parties (International Institute for Democracy and Electoral Assistance:

Stockholm).

Carroll, Barbara Wake, and Terrance Carroll, 1991, "State and Ethnicity in Botswana and Mauritius: A Democratic Route to Development?” Journal of Development Studies 33, no. 4, April, 464-486.

Collier, Paul, 2000, “Ethnicity, Politics and Economic Peformance,” Economics and Politics 12, 225-45.

Collier, Paul, and Robert Bates, with Anke Hoeffler and Stephen O’Connell, 2008, "Endogenizing

Syndromes," in The Political Economy of Economic Growth in Africa:1960-2000. (Cambridge University

Press: Cambridge UK and NY)

Collier, Paul, and Anke Hoeffler, 2009, "Testing the Neo-con Agenda: Democracy in Resource-Rich Societies,” European Economic Review 53, 293-308.

Dukhira, Chit, 2002, History of Mauritius: Experiments in Democracy [publisher: Dukhira. Printed by Brijbasi Art Press, New Delhi.]

Easterly, William, and Ross Levine, 1997, “Africa’s Growth Tragedy: Politics and Ethnic Divisions,” Quarterly Journal of Economics.

Easterly, William, and Ross Levine, 2002, “Tropics, Germs, and Endowments," Carnegie-Rochester Conference Series on Public Policy. NBER Working Paper No. 9106.

Engerman, Stanley, and Kenneth Sokoloff, 1997, "Factor Endowments, Institutions, and Differential Paths of Growth among New World Economies: A View From Economic Historians of the United States," in How Latin America Fell Behind, edited by Stephen Haber (Stanford University Press), 260-304.

Engerman, Stanley, and Kenneth Sokoloff, 2000, "Institutions, Factor Endowments, and Paths of Development in the New World,” Journal of Economic Perspectives XIV: 217-232.

Engerman, Stanley, and Kenneth Sokoloff, 2002, "Factor Endowments, Inequality, and Paths of Development Among New World Economies,” Working Paper 9259, October.

Feyrer, James, and Bruce Sacerdote, 2009, "Colonialism and Modern Income: Islands as Natural Experiments,” Review of Economics and Statistics 91, no. 2, May: 245-262.

Frankel, Jeffrey, 1974, “Cocoa in Ghana: The Cocoa Farmers, Cocoa Marketing Board, and Elasticity of Supply,” MIT. At http://www.hks.harvard.edu/fs/jfrankel/cocoa_in_ghana.pdf .

Frankel, Jeffrey, 1997, Regional Trading Blocs (Institute for International Economics, Washington DC).

Frankel, Jeffrey, “The Natural Resource Curse,” 2010, forthcoming in Export Perils (University of Pennsylvania Press), edited by Brenda Shaffer. Center for International Development, WP No. 195, Harvard University, May.

Frankel, Jeffrey, and David Romer, 1999, “Trade and Growth: Cause and Effect?” AER. 89, no. 3, June, 379-99.

Frazer, Garth, and Johannes Van Biesebroeck, 2010, "Trade and Growth Under the African Growth and Opportunity Act,” Review of Economics and Statistics, Feb., 92, no. 1, 128-144.

Gulhati, Ravi, and Raj Nallari, 1990, Successful stabilization and recovery in Mauritius,” EDI development policy case series. Analytical case studies, no. 5 (World Bank, Washington DC) 
Hausmann, Ricardo, and Roberto Rigobon, 2003, “An Alternative Interpretation of the 'Resource Curse': Theory and Policy Implications," in Fiscal Policy Formulation and Implementation in Oil-Producing Countries, edited by Jeffrey Davis (International Monetary Fund: Washington, DC), p 12-44.

Hausmann, Ricardo, and Dani Rodrik, 2003, “Economic Development as Self-Discovery,” Journal of Development Economics 72 (2) 603-633.

Helliwell, John, 1994, “Empirical Linkages Between Democracy and Economic Growth,” British Journal of Political Science 24, 225-248.

[Hinkle, L. E., and A. Herrou-Aragon, 2001, How Far Did Africa’s First Generation Trade Reforms Go? World Bank. "do not cite" ]

Huber, Evelyne, Dietrich Rueschemeyer, and John Stephens, 1993, "The Impact of Economic Development on Democracy." Journal of Economic Perspectives 7, 71-85.

Iman, Patrick, and Camelia Manoiu, 2008, “Mauritius: A Competitiveness Assessment,” IMF working paper 08/212, Sept.

Isham, Jonathan, Michael Woolcock, Lant Pritchett, and Gwen Busby, 2005, "The Varieties of Resource Experience: Natural Resource Export Structures and the Political Economy of Economic Growth,” The World Bank Economic Review (Oxford University Press).

Lange, Matthew, 2009, Lineages of Despotism and Development: British Colonialism and State Power, Chapter 4, (University of Chicago Press).

Leuprecht, Christian, 2008-09, "Migration as the Demographic Wild Card in Civil Conflict: Mauritius and Fiji," New Directions in Demographic Security, Environmental Change and Security Program Report, issue 13, pp. 34-39.

Lipset, Seymour Martin, 1994, "The Social Requisites of Democracy Revisited." American Sociological Review 59, 1-22.

Lutz, Wolfgang, and Anne B. Wils, 1990, “The Demographic Discontinuities of Mauritius,” Chapter 4 in Wolfgang Lutz and F.L. Toth, editors, Population, Economy and Environment in Mauritius, International Institute for Applied Systems Analysis, Laxenburg, Austria, p.39-66.

\section{Macedo, Jorge Braga de, and Luís Brites Per eira, 2009, "Cape Verde and M ozambique as Development Successes in Sub-Saharan Africa," NBER Confer ence on African Successes.}

Matsuyama, Kiminori, 1992, "Agricultural Productivity, Comparative Advantage, and Economic Growth," Journal of Economic Theory 58, December, 317-334.

Meade, James, 1961, The Economics and Social Structure of Mauritius—Report to Government of Mauritius (Methuen: London).

Mehlum, Halvor, Karl Moene, and Ragnar Torvik, 2006, “Institutions and the Resource Curse," Economic Journal 116, 508, 1-20.

Minier, Jenny A., 1998, “Democracy and Growth: Alternative Approaches," Journal of Economic Growth 3, 241-266.

Ministry of Finance, 2008, “Additional Stimulus Package: Shoring Up Economic Performance,” Mauritius.

Naipaul, V.S., 1972, The Overcrowded Barracoon (Random House). 
Nath, Shyam and Neti Madhoo, 2008 "A Shared Growth Story of Economic Success: The Case of Mauritius," in The Political Economy of Economic Growth in Africa, B. J. Ndulu, Stephen A. O'Connell, Jean-Paul Azam, eds. Vol. 2 (Cambridge University Press)

North, Douglass, 1994, “Economic Performance Through Time,” American Economic Review, 84, no. 3, June, 359-368.

Poelhekke, Steven, and, Frederick van der Ploeg, 2007, "Volatility, Financial Development and the Natural Resource Curse,” CEPR DP6513, October.

Radelet, Steven, 2010, Emerging Africa: How 17 Countries Are Leading the Way (Center for Global Development: Washington DC).

Rodriguez, Francisco, and Dani Rodrik, 2001, "Trade Policy and Economic Growth: A Skeptic's Guide to the Cross-National Evidence," in: NBER Macroeconomics Annual 2000, Volume 15, pages 261-338.

Rodrik, Dani, 1997, “Trade Policy and Economic Performance in Sub-Saharan Africa,” Swedish Ministry for Foreign Affairs.

Rodrik, Dani, Arvind Subramanian, and Francesco Trebbi, 2004, "Institutions Rule: The Primacy of Institutions over Geography and Integration in Economic Development," Journal of Economic Growth 9 no. 2, 131-65.

Romer, Paul, 1990, "Endogenous Technological Change," 1990, Journal of Political Economy. Vol.98, No. 5, Oct., pp. S71-S102.

Romer, Paul, 1992, “Two Strategies for Economic Development: Using Ideas and Producing Ideas,” $A B C D E$, World Bank.

Romer, Paul, 1993, “Idea Gaps and Object Gaps in Economic Development,” Journal of Monetary Economics, Volume 32, Issue 3, December, Pages 543-573.

Rotberg, Robert, and Rachel Gisselquist, 2007, 2008, and 2009, Strengthening African Governance: Index of African Governance Results and Rankings, Harvard Kennedy School.

Sachs, Jeffrey, 2003, “Institutions Don’t Rule: Direct Effects of Geography on Per Capita Income,” NBER WP 9490, February.

Sachs, Jeffrey and Andrew Warner, 1997, “Sources of Slow Growth in African Economies," Journal of African Economies, 6 (3): 335-76.

Sala-i-Martin, Xavier X., 1997, “I Just Ran Two Million Regressions,” American Economic Review, May.

Sala-I-Martin, Xavier, and Arvind Subramanian, 2003, “Addressing the Natural Resource Curse: An Illustration from Nigeria.” IMF Working Paper WP/03/139.

Selvon, Sydney, 2005, A Comprehensive History of Mauritius ( $2^{\text {nd }}$ edition; publisher: Selvon).

Simmons, Adele, 1982, Modern Mauritius : The Politics of Decolonization (Indiana University Press, Bloomington).

Subramanian, Arvind, 2001, “Mauritius: A Case Study,” Finance and Development, IMF, Dec., 38, no. 4. Subramanian, Arvind, 2007, “The Mauritian Success Story and Its Lessons," UN/WIDER Research Paper No. 2009/36 2009. 
Subramanian Arvind, and Roy Devesh, 2003, "Who can Explain the Mauritian Miracle: Meade, Romer, Sachs, or Rodrik?” in Rodrik, ed., In Search of Prosperity: Analytic Narratives on Economic Growth (Princeton U. Press).

Torvik, Ragnar, 2001, “Learning by Doing and the Dutch Disease,” European Economic Review (Elsevier) 45, 285-306.

Wright, Gavin, and Jesse Czelusta, 2003, “Mineral Resources and Economic Development,” Conference on Sector Reform in Latin America, Stanford Center for International Development Nov. 13-15.

Wright, Gavin, and Jesse Czelusta, 2006, “Resource-Based Growth Past and Present,” in Daniel Lederman and William Maloney, editors, Neither Curse nor Destiny: Natural Resources and Development (Stanford University Press and World Bank Publication).

Zakaria, Fareed, 1997, “The Rise of Illiberal Democracy,” Foreign Affairs, November.

Zakaria, Fareed, 2004, The Future of Freedom: Illiberal Democracy at Home and Abroad (Norton: NY). 
Table 2: Performance of Sub-Saharan African Countries

\begin{tabular}{|c|c|c|c|c|c|c|c|}
\hline \multirow[b]{2}{*}{ Country } & \multirow{2}{*}{$\begin{array}{c}\text { GDP per } \\
\text { capita, PPP } \\
\text { (Constant 2005 } \\
\text { International \$) }\end{array}$} & \multirow[b]{2}{*}{$\begin{array}{l}\text { Population, } \\
\text { Millions }\end{array}$} & \multicolumn{2}{|c|}{$\begin{array}{l}\text { Average annual GDP growth } \\
\text { rate (Constant 2000\$) }\end{array}$} & \multirow{2}{*}{$\begin{array}{l}\text { World Governance } \\
\text { Indicators, Rule of } \\
\text { Law Index Ranking }\end{array}$} & \multirow{2}{*}{$\begin{array}{l}\text { Index of } \\
\text { African } \\
\text { Governance } \\
\text { Ranking }\end{array}$} & \multirow{2}{*}{$\begin{array}{l}\text { UN Human } \\
\text { Development } \\
\text { Ranking }\end{array}$} \\
\hline & & & $\overline{1968-1976}$ & $1977-2006$ & & & \\
\hline Angola & 4163.76 & 16.56 & & & 39 & 44 & 13 \\
\hline Benin & 1319.02 & 8.76 & $1.55 \%$ & $3.81 \%$ & 18 & 13 & 26 \\
\hline Botswana & 12252.27 & 1.86 & $15.28 \%$ & $7.85 \%$ & 2 & 4 & 6 \\
\hline Burkina Faso & 1060.48 & 14.36 & $3.17 \%$ & $4.49 \%$ & 14 & 20 & 41 \\
\hline Burundi & 347.02 & 8.17 & $3.53 \%$ & $1.42 \%$ & 34 & 35 & 40 \\
\hline Cameroon & 1972.82 & 18.17 & $4.29 \%$ & $3.15 \%$ & 32 & 25 & 19 \\
\hline Cape Verde & 2796.55 & 0.52 & & & 3 & 3 & 5 \\
\hline C.A.R. & 670.82 & 4.26 & $3.00 \%$ & $0.68 \%$ & 45 & 43 & 43 \\
\hline Chad & 1304.66 & 10.47 & $1.88 \%$ & $4.16 \%$ & 42 & 46 & 38 \\
\hline Comoros & 1116.86 & 0.61 & & & 29 & 14 & 11 \\
\hline Congo (Brazz.) & 3640.58 & 3.69 & $6.63 \%$ & $4.10 \%$ & 38 & 28 & 10 \\
\hline Congo (DR) & 271.55 & 60.64 & $1.87 \%$ & $-0.94 \%$ & 47 & 47 & 42 \\
\hline Cote d'Ivoire & 1536.51 & 18.91 & $7.78 \%$ & $1.09 \%$ & 44 & 42 & 28 \\
\hline Djibouti & 1889.75 & 0.82 & & & 22 & 26 & 21 \\
\hline Eq. Guinea & 24416.68 & 0.50 & & & 37 & 36 & 4 \\
\hline Eritrea & 609.91 & 4.69 & & & 31 & 41 & 30 \\
\hline Ethiopia & 683.38 & 77.15 & & & 19 & 31 & 36 \\
\hline Gabon & 12933.20 & 1.31 & $15.95 \%$ & $0.68 \%$ & 25 & 8 & 3 \\
\hline Gambia & 1181.91 & 1.66 & $5.24 \%$ & $3.65 \%$ & 9 & 27 & 33 \\
\hline Ghana & 1242.08 & 23.01 & $1.29 \%$ & $3.46 \%$ & 7 & 7 & 20 \\
\hline Guinea & 955.95 & 9.18 & & & 43 & 40 & 35 \\
\hline Guinea-Bissau & 489.09 & 1.65 & & $2.02 \%$ & 40 & 30 & 39 \\
\hline Kenya & 1386.43 & 36.55 & $6.43 \%$ & $3.51 \%$ & 28 & 17 & 15 \\
\hline Lesotho & 1345.99 & 1.99 & $4.79 \%$ & $3.82 \%$ & 8 & 12 & 22 \\
\hline Liberia & 334.31 & 3.58 & $3.29 \%$ & $-3.55 \%$ & 30 & 38 & 34 \\
\hline Madagascar & 901.25 & 19.16 & $1.10 \%$ & $1.59 \%$ & 12 & 16 & 14 \\
\hline Malawi & 660.13 & 13.57 & $5.91 \%$ & $2.83 \%$ & 15 & 11 & 27 \\
\hline Mali & 1012.80 & 11.97 & $4.40 \%$ & $2.95 \%$ & 11 & 23 & 44 \\
\hline Mauritania & 1820.52 & 3.04 & $2.92 \%$ & $2.86 \%$ & 20 & 32 & 18 \\
\hline Mauritius & 10476.46 & 1.25 & $8.00 \%^{1}$ & $4.34 \%$ & 1 & 1 & 2 \\
\hline Mozambique & 707.77 & 20.97 & & & 26 & 22 & 37 \\
\hline Namibia & 5659.85 & 2.05 & & & 6 & 6 & 8 \\
\hline Niger & 602.68 & 13.74 & $-1.86 \%$ & $2.07 \%$ & 27 & 24 & 46 \\
\hline Nigeria & 1800.82 & 144.70 & $9.97 \%$ & $2.71 \%$ & 35 & 39 & 23 \\
\hline Rwanda & 833.97 & 9.46 & $4.77 \%$ & $3.11 \%$ & 23 & 18 & 32 \\
\hline Sao Tome \& P. & 1486.65 & 0.16 & & & 17 & 9 & 9 \\
\hline Senegal & 1611.75 & 12.07 & $2.71 \%$ & $2.78 \%$ & 10 & 10 & 31 \\
\hline Seychelles & 18414.93 & 0.08 & $7.19 \%$ & $3.76 \%$ & 5 & 2 & 1 \\
\hline Sierra Leone & 678.64 & 5.74 & $3.45 \%$ & $1.54 \%$ & 36 & 37 & 45 \\
\hline Somalia & & 8.45 & & & 48 & 48 & N/A \\
\hline South Africa & 8861.93 & 47.39 & $3.73 \%$ & $2.42 \%$ & 4 & 5 & 7 \\
\hline Sudan & 1743.57 & 37.71 & $5.70 \%$ & $3.82 \%$ & 41 & 45 & 16 \\
\hline Swaziland & 4410.90 & 1.14 & & $5.02 \%$ & 24 & 34 & 12 \\
\hline Tanzania & 1104.95 & 39.46 & & & 13 & 15 & 17 \\
\hline Togo & 782.19 & 6.41 & $3.62 \%$ & $2.25 \%$ & 33 & 29 & 25 \\
\hline Uganda & 966.31 & 29.90 & & & 16 & 19 & 24 \\
\hline Zambia & 1168.84 & 11.70 & $2.75 \%$ & $1.62 \%$ & 21 & 21 & 29 \\
\hline Zimbabwe & & 13.23 & $7.01 \%$ & & 46 & 33 & N/A \\
\hline
\end{tabular}


Table 3: Islands Cross-section

\begin{tabular}{|c|c|c|c|c|c|c|}
\hline & \multicolumn{6}{|c|}{ Log of 2006 GDP per capita, PPP } \\
\hline Tropicdummy & $\begin{array}{c}-1.811 * * * \\
(0.328)\end{array}$ & $\begin{array}{c}-1.725 * * * \\
(0.330)\end{array}$ & $\begin{array}{l}-0.605^{*} \\
(0.351)\end{array}$ & $\begin{array}{c}-1.800^{* * *} \\
(0.405)\end{array}$ & $\begin{array}{c}-1.961 * * * \\
(0.364)\end{array}$ & $\begin{array}{l}-0.342 \\
0.400\end{array}$ \\
\hline L_pop & $\begin{array}{c}-0.0870 * \\
(0.0497) \\
\end{array}$ & $\begin{array}{l}-0.0914 * \\
(0.0495) \\
\end{array}$ & $\begin{array}{l}-0.0123 \\
(0.0441) \\
\end{array}$ & $\begin{array}{c}-0.0860 \\
(0.0551) \\
\end{array}$ & $\begin{array}{l}-0.121^{*} \\
(0.0692)\end{array}$ & $\begin{array}{l}0.032 \\
0.053\end{array}$ \\
\hline Tradey & $\begin{array}{c}0.00569 * * * \\
(0.00131)\end{array}$ & $\begin{array}{c}0.00552^{* * *} \\
(0.00129)\end{array}$ & $\begin{array}{c}0.00313^{* *} \\
(0.00125)\end{array}$ & $\begin{array}{c}0.00578 * * * \\
(0.00193)\end{array}$ & $\begin{array}{c}0.00534 * * * \\
(0.00126)\end{array}$ & \\
\hline Remoteness & $\begin{array}{l}-0.234 \\
(0.463)\end{array}$ & $\begin{array}{l}-0.140 \\
(0.477)\end{array}$ & $\begin{array}{l}-0.338 \\
(0.346)\end{array}$ & $\begin{array}{l}-0.251 \\
(0.439)\end{array}$ & $\begin{array}{c}-0.601 \\
(0.568)\end{array}$ & $\begin{array}{c}-0.773^{* *} \\
0.344 \\
\end{array}$ \\
\hline Africa & & $\begin{array}{l}-0.537 \\
(0.457)\end{array}$ & & & & \\
\hline WGI & & & $\begin{array}{c}0.731^{* * *} \\
(0.155) \\
\end{array}$ & & & $\begin{array}{c}0.826^{* * *} \\
0.183 \\
\end{array}$ \\
\hline L_pden & & & & $\begin{array}{c}-0.00833 \\
(0.124)\end{array}$ & & \\
\hline fragment & & & & & $\begin{array}{c}4.189 \\
(2.905)\end{array}$ & \\
\hline fragmentsq & & & & & $\begin{array}{l}-3.177 \\
(5.902)\end{array}$ & \\
\hline Constant & $\begin{array}{c}13.02 * * * \\
(3.789) \\
\end{array}$ & $\begin{array}{c}12.31 * * * \\
(3.819) \\
\end{array}$ & $\begin{array}{c}11.91 * * * \\
(2.796) \\
\end{array}$ & $\begin{array}{c}13.17 * * * \\
(3.488) \\
\end{array}$ & $\begin{array}{c}15.79 * * * \\
(5.076) \\
\end{array}$ & $\begin{array}{c}15.018^{* * *} \\
2.766 \\
\end{array}$ \\
\hline Rsq & 0.570 & 0.594 & 0.694 & 0.570 & 0.625 & 0.6246 \\
\hline Root MSE & 0.839 & 0.830 & 0.730 & 0.855 & 0.836 & .77857 \\
\hline Obs & 33 & 33 & 32 & 33 & 31 & 37 \\
\hline
\end{tabular}

* significant at 10 percent level,

** significant at 5 percent level

*** significant at 1 percent level

Robust standard errors are reported below the coefficients in parentheses 


\section{Table 4a: Islands from 1968}

\begin{tabular}{|c|c|c|c|c|}
\hline \multicolumn{5}{|c|}{ Log of 2006 GDP per capita in constant year 2000 dollars } \\
\hline L_Ypc2k1968 & $\begin{array}{r}1.003^{* * * *} \\
(0.108) \\
\end{array}$ & $\begin{array}{r}1.004^{* * *} \\
(0.138)\end{array}$ & $\begin{array}{r}0.956 * * * \\
(0.103)\end{array}$ & $\begin{array}{r}0.967 * * * \\
(0.107)\end{array}$ \\
\hline L_Pop1968 & $\begin{array}{r}-0.017 \\
(0.047) \\
\end{array}$ & $\begin{array}{r}0.168 \\
(0.270) \\
\end{array}$ & $\begin{array}{r}-0.004 \\
(0.048) \\
\end{array}$ & $\begin{array}{r}0.008 \\
(0.041) \\
\end{array}$ \\
\hline Tradey6872 & & $\begin{array}{r}0.011 \\
(0.016) \\
\end{array}$ & & \\
\hline L_Pden1968 & & $\begin{array}{r}0.010 \\
(0.125) \\
\end{array}$ & & \\
\hline Remoteness & & $\begin{array}{r}-0.731 \\
(0.445) \\
\end{array}$ & $\begin{array}{r}-0.690 * * \\
(0.321) \\
\end{array}$ & \\
\hline Fragment & & & & $\begin{array}{r}-9.065^{* *} \\
(3.224) \\
\end{array}$ \\
\hline Fragmentsq & & & & $\begin{array}{r}11.535 * * \\
(5.115) \\
\end{array}$ \\
\hline Cons & $\begin{array}{r}1.138 \\
(0.985) \\
\end{array}$ & $\begin{array}{r}3.715 \\
(5.966) \\
\end{array}$ & $\begin{array}{c}7.171^{* *} \\
(2.873) \\
\end{array}$ & $\begin{array}{r}2.551^{* *} \\
(0.859) \\
\end{array}$ \\
\hline Rsq & 0.8325 & 0.9103 & 0.8511 & 0.8793 \\
\hline Root MSE & .66361 & .6263 & .64503 & .59983 \\
\hline Obs & 20 & 15 & 20 & 20 \\
\hline
\end{tabular}




\section{Table 4b: Islands from 1976}

\begin{tabular}{|l|r|r|r|r|r|}
\hline \multicolumn{6}{|c}{ Log of 2006 GDP per capita in constant year 2000 dollars } \\
\hline L_Ypc2k1976 & $\begin{array}{r}1.035^{* * *} \\
(0.096)\end{array}$ & $\begin{array}{r}1.083^{* * *} \\
(0.082)\end{array}$ & $\begin{array}{r}1.033^{* * *} \\
(0.089)\end{array}$ & $\begin{array}{r}0.977^{* * *} \\
(0.089)\end{array}$ & $\begin{array}{r}1.026^{* * *} \\
(0.113)\end{array}$ \\
\hline L_Pop1976 & 0.034 & $0.218^{* *}$ & $0.190^{*}$ & 0.038 & 0.040 \\
& $(0.053)$ & $(0.078)$ & $(0.092)$ & $(0.050)$ & $(0.052)$ \\
\hline Tradey7680 & & $0.012^{* * *}$ & $0.010^{*}$ & & \\
& & $(0.004)$ & $(0.005)$ & & \\
\hline L_Pden1976 & & & -0.020 & & \\
& & & $(0.086)$ & & \\
\hline Remoteness & & & -0.522 & $-0.802^{* *}$ & \\
& & & $(0.344)$ & $(0.284)$ & \\
\hline Fragment & & & & & $-6.060^{*}$ \\
& & & & & $(2.990)$ \\
\hline Fragmentsq & & & & & $8.412^{*}$ \\
& & & & & $(4.787)$ \\
\hline Cons & -0.175 & $-4.298^{* *}$ & 1.215 & $7.055^{*}$ & 0.727 \\
& $(1.194)$ & $(1.641)$ & $(3.930)$ & $(2.456)$ & $(1.300)$ \\
\hline Rsq & 0.8649 & 0.9215 & 0.9302 & 0.8906 & 0.8800 \\
\hline Root MSE & .57133 & .46467 & .46616 & .52690 & .56627 \\
\hline Obs & 24 & 21 & 21 & 24 & 24 \\
\hline
\end{tabular}




\section{Table 4c: Islands, from 1996}

\begin{tabular}{|c|c|c|c|c|c|c|}
\hline \multicolumn{7}{|c|}{ Log of 2006 GDP per capita in constant year 2000 dollars } \\
\hline L_Ypc2k1996 & $\begin{array}{r}1.037^{* * *} \\
(0.022) \\
\end{array}$ & $\begin{array}{r}1.017^{* * * *} \\
(0.024) \\
\end{array}$ & $\begin{array}{r}1.024^{* * *} \\
(0.022) \\
\end{array}$ & $\begin{array}{r}0.918^{* * *} \\
(0.049) \\
\end{array}$ & $\begin{array}{r}0.894 * * * \\
(0.043) \\
\end{array}$ & $\begin{array}{r}0.945^{* * *} \\
(0.049) \\
\end{array}$ \\
\hline L_Pop1996 & $\begin{array}{r}0.000 \\
(0.011)\end{array}$ & $\begin{array}{r}0.000 \\
(0.010)\end{array}$ & $\begin{array}{r}0.012 \\
(0.013)\end{array}$ & $\begin{array}{r}-0.020 \\
(0.021)\end{array}$ & $\begin{array}{r}-0.017 \\
(0.020)\end{array}$ & $\begin{array}{c}-0.002 \\
(0.015)\end{array}$ \\
\hline Tradey9600 & & & $\begin{array}{r}0.002 * * \\
(0.001)\end{array}$ & $\begin{array}{r}0.000 \\
(0.001) \\
\end{array}$ & $\begin{array}{r}0.000 \\
(0.001) \\
\end{array}$ & $\begin{array}{c}0.001 * \\
(0.001)\end{array}$ \\
\hline L_Pden1996 & & & & $\begin{array}{r}0.050 \\
(0.031)\end{array}$ & $\begin{array}{r}0.040 \\
(0.030)\end{array}$ & \\
\hline WGI1996 & & & & $\begin{array}{r}0.216^{* *} \\
(0.097)\end{array}$ & $\begin{array}{r}0.233^{* *} \\
(0.089 \\
\end{array}$ & $\begin{array}{l}0.157^{*} \\
(0.085)\end{array}$ \\
\hline Remoteness & & $\begin{array}{r}-0.237^{* *} \\
(0.110) \\
\end{array}$ & & & $\begin{array}{l}-0.207 * \\
(0.104)\end{array}$ & \\
\hline Cons & $\begin{array}{l}-0.106 \\
(0.246)\end{array}$ & $\begin{array}{r}2.089 * * \\
(1.026)\end{array}$ & $\begin{array}{r}-0.355 \\
(0.274)\end{array}$ & $\begin{array}{r}0.838 \\
(0.525)\end{array}$ & $\begin{array}{r}2.797 * * \\
(0.988)\end{array}$ & $\begin{array}{r}0.489 \\
(0.476)\end{array}$ \\
\hline$\overline{\text { Rsq }}$ & 0.9793 & 0.9812 & 0.9818 & 0.9896 & 0.9908 & 0.9878 \\
\hline Root MSE & 20375 & .19711 & .19942 & .18747 & .18214 & .19736 \\
\hline Obs & 40 & 40 & 36 & 22 & 22 & 22 \\
\hline
\end{tabular}




\section{Table 5a: Africa Cross-section}

\begin{tabular}{|l|c|c|c|c|}
\hline & \multicolumn{4}{|c|}{ Log of 2006 GDP per capita, PPP } \\
\hline Tradey & $\begin{array}{c}0.0108^{* * *} \\
(0.00294)\end{array}$ & $\begin{array}{c}0.00968^{* * *} \\
(0.00311)\end{array}$ & $\begin{array}{c}0.0111^{* * *} \\
(0.00292)\end{array}$ & $\begin{array}{c}0.0100^{* * *} \\
(0.00308)\end{array}$ \\
\hline L_pop & $\begin{array}{c}-0.337^{* *} \\
(0.155)\end{array}$ & $\begin{array}{c}-0.285^{*} \\
(0.152)\end{array}$ & $\begin{array}{c}-0.141 \\
(0.106)\end{array}$ & $\begin{array}{c}-0.0703 \\
(0.102)\end{array}$ \\
\hline L_area & $\begin{array}{c}0.196^{* *} \\
(0.0873)\end{array}$ & $\begin{array}{c}0.214^{* *} \\
(0.0940)\end{array}$ & & \\
\hline L_pden & & & $-0.190^{* *}$ & $-0.209 * *$ \\
$(0.0872)$ & $(0.0936)$ \\
\hline FHdemyrs & $0.0257 *$ & -0.00879 & $0.0257 *$ & -0.00881 \\
& $(0.0130)$ & $(0.0166)$ & $(0.0130)$ & $(0.0166)$ \\
\hline Rule & & $0.0347 * *$ & & $0.0347 * *$ \\
& & $(0.0131)$ & & $(0.0131)$ \\
\hline Constant & $9.172^{* * *}$ & $6.713^{* * *}$ & $9.120^{* * *}$ & $6.658^{* * *}$ \\
& $(1.966)$ & $(2.111)$ & $(1.959)$ & $(2.106)$ \\
\hline \hline Rsq & 0.438 & 0.541 & 0.435 & 0.538 \\
\hline Root MSE & 0.858 & 0.785 & 0.860 & 0.787 \\
\hline Obs & 43 & 43 & 43 & 43 \\
\hline
\end{tabular}




\section{Table 5b: Africa Cross-section with coastal variable}

\begin{tabular}{|c|c|c|c|c|c|c|}
\hline \multirow[b]{2}{*}{ Coast_Area } & \multicolumn{6}{|c|}{ Log of 2006 GDP per capita, PPP } \\
\hline & $\begin{array}{c}0.00595 \\
(0.528) \\
\end{array}$ & $\begin{array}{l}0.690 * * \\
(0.341) \\
\end{array}$ & $\begin{array}{l}-0.0363 \\
(0.539) \\
\end{array}$ & $\begin{array}{c}0.727 * * \\
(0.346) \\
\end{array}$ & $\begin{array}{l}0.0658 \\
(0.514) \\
\end{array}$ & $\begin{array}{l}0.683 * * \\
(0.330)\end{array}$ \\
\hline Rule & $\begin{array}{c}0.0314^{* * *} \\
(0.0105) \\
\end{array}$ & $\begin{array}{c}0.0339 * * * \\
(0.00969)\end{array}$ & $\begin{array}{c}0.0289 * * * \\
(0.0106) \\
\end{array}$ & $\begin{array}{l}0.0304^{* * *} \\
(0.00979)\end{array}$ & $\begin{array}{c}0.0300^{* * *} \\
(0.0102) \\
\end{array}$ & $\begin{array}{c}0.0297^{* * *} \\
(0.0100)\end{array}$ \\
\hline Tradey & $\begin{array}{c}0.00908^{* *} \\
(0.00433)\end{array}$ & & $\begin{array}{l}0.0101^{* *} \\
(0.00434)\end{array}$ & & $\begin{array}{c}0.00964 * * \\
(0.00424)\end{array}$ & \\
\hline L_pop & $\begin{array}{l}-0.293^{*} \\
(0.154) \\
\end{array}$ & $\begin{array}{c}-0.402^{* *} \\
(0.150) \\
\end{array}$ & $\begin{array}{l}-0.293^{*} \\
(0.156) \\
\end{array}$ & $\begin{array}{c}-0.415^{* *} \\
(0.158) \\
\end{array}$ & $\begin{array}{l}-0.294 * \\
(0.154) \\
\end{array}$ & $\begin{array}{c}-0.416^{* *} \\
(0.158) \\
\end{array}$ \\
\hline L_area & $\begin{array}{l}0.221^{* *} \\
(0.0985) \\
\end{array}$ & $\begin{array}{l}0.225^{* *} \\
(0.0922) \\
\end{array}$ & $\begin{array}{l}0.234^{* *} \\
(0.0990) \\
\end{array}$ & $\begin{array}{l}0.237 * * \\
(0.0944)\end{array}$ & $\begin{array}{l}0.218^{* *} \\
(0.0981)\end{array}$ & $\begin{array}{l}0.250 * * \\
(0.0972)\end{array}$ \\
\hline Landl & $\begin{array}{l}-0.354 \\
(0.228)\end{array}$ & $\begin{array}{c}-0.519^{* *} \\
(0.233)\end{array}$ & & & & \\
\hline Island & $\begin{array}{l}0.0286 \\
(0.516) \\
\end{array}$ & $\begin{array}{l}-0.395 \\
(0.446) \\
\end{array}$ & $\begin{array}{c}0.237 \\
(0.511) \\
\end{array}$ & $\begin{array}{l}-0.154 \\
(0.436) \\
\end{array}$ & & \\
\hline Cons & $\begin{array}{c}7.005^{* * *} \\
(2.212) \\
\end{array}$ & $\begin{array}{c}9.327^{* * *} \\
(2.183) \\
\end{array}$ & $\begin{array}{c}6.772 * * * \\
(2.256) \\
\end{array}$ & $\begin{array}{c}9.385^{* * *} \\
(2.290) \\
\end{array}$ & $\begin{array}{c}6.966 * * * \\
(2.136) \\
\end{array}$ & $\begin{array}{c}9.283^{* * *} \\
(2.178) \\
\end{array}$ \\
\hline Rsq & 0.560 & 0.501 & 0.540 & 0.454 & 0.538 & 0.453 \\
\hline Root MSE & 0.790 & 0.806 & 0.797 & 0.832 & 0.788 & 0.822 \\
\hline Obs & 43 & 46 & 43 & 46 & 43 & 46 \\
\hline
\end{tabular}




\section{Table 6a: Africa from 1960}

\begin{tabular}{|c|c|c|c|c|}
\hline & \multicolumn{4}{|c|}{$\begin{array}{c}\text { Log of } 2006 \text { GDP per capita in constant year } 2000 \\
\text { dollars }\end{array}$} \\
\hline \multirow[t]{2}{*}{ l_yрс2k1960 } & $0.809 * * *$ & $0.743 * *$ & $0.726 * * *$ & $0.770 * * *$ \\
\hline & $(0.217)$ & $(0.319)$ & $(0.238)$ & $(0.184)$ \\
\hline \multirow[t]{2}{*}{ Tradey6064 } & -0.002 & -0.002 & -0.008 & -0.014 \\
\hline & $(0.008)$ & $(0.008)$ & $(0.010)$ & $(0.009)$ \\
\hline \multirow[t]{2}{*}{ L_pop1960 } & -0.239 & -0.203 & -0.199 & -0.196 \\
\hline & $(0.216)$ & $(0.198)$ & $(0.206)$ & $(0.213)$ \\
\hline \multirow[t]{2}{*}{ L_pden $1960^{1}$} & & -0.099 & -0.160 & -0.212 \\
\hline & & $(0.223)$ & $(0.209)$ & $(0.204)$ \\
\hline \multirow[t]{2}{*}{ Remoteness } & & & 2.612 & $3.933 * *$ \\
\hline & & & $(1.817)$ & $(1.576)$ \\
\hline \multirow[t]{2}{*}{ island } & & & & $-1.747 * * *$ \\
\hline & & & & $(0.525)$ \\
\hline \multirow[t]{2}{*}{ Cons } & 4.966 & 5.064 & -16.770 & $-27.851^{* *}$ \\
\hline & (3.851) & $(4.100)$ & $(14.682)$ & $(12.670)$ \\
\hline Rsq & 0.4065 & 0.4165 & 0.5072 & 0.5940 \\
\hline Root MSE & .86818 & .88318 & .83387 & .77887 \\
\hline Obs & 24 & 24 & 24 & 24 \\
\hline
\end{tabular}

${ }^{1}$ No data for land area in 1960, so density is 1960 population / area in 1961 


\section{Table 6b: Africa from 1968}

\begin{tabular}{|c|c|c|c|c|c|c|c|c|}
\hline & \multicolumn{8}{|c|}{ Log of 2006 GDP per capita in constant year 2000 dollars } \\
\hline l_ypc2k1968 & $\begin{array}{r}0.851^{* * *} \\
(0.141) \\
\end{array}$ & $\begin{array}{r}0.890 * * * \\
(0.192) \\
\end{array}$ & $\begin{array}{r}0.825 * * * \\
(0.243) \\
\end{array}$ & $\begin{array}{r}0.780 * * * \\
(0.199) \\
\end{array}$ & $\begin{array}{r}0.811 \\
(0.171) \\
\end{array}$ & $\begin{array}{r}0.902 * * * \\
(0.147) \\
\end{array}$ & $\begin{array}{r}0.795^{* * *} \\
(0.136)\end{array}$ & $\begin{array}{r}0.851^{* * *} \\
(0.147)\end{array}$ \\
\hline L_pop1968 & $\begin{array}{r}-0.176 \\
(0.126) \\
\end{array}$ & $\begin{array}{r}-0.205 \\
(0.199) \\
\end{array}$ & $\begin{array}{r}-0.173 \\
(0.188) \\
\end{array}$ & $\begin{array}{r}-0.213 \\
(0.214) \\
\end{array}$ & $\begin{array}{l}-0.242 \\
(0.222) \\
\end{array}$ & $\begin{array}{r}-0.097 \\
(0.144) \\
\end{array}$ & $\begin{array}{r}-0.172 \\
(0.115) \\
\end{array}$ & $\begin{array}{r}-0.176 \\
(0.138) \\
\end{array}$ \\
\hline Tradey6872 & & $\begin{array}{r}-0.006 \\
(0.011) \\
\end{array}$ & $\begin{array}{r}-0.005 \\
(0.011) \\
\end{array}$ & $\begin{array}{r}-0.009 \\
(0.011) \\
\end{array}$ & $\begin{array}{r}-0.013 \\
(0.010) \\
\end{array}$ & & & \\
\hline l_pden1968 & & & $\begin{array}{r}-0.098 \\
(0.149) \\
\end{array}$ & $\begin{array}{l}-0.148 \\
(0.151)\end{array}$ & $\begin{array}{r}-0.178 \\
(0.150) \\
\end{array}$ & & & \\
\hline Remoteness & & & & $\begin{array}{r}1.976 \\
(1.498) \\
\end{array}$ & $\begin{array}{l}2.834 * \\
(1.422) \\
\end{array}$ & & $\begin{array}{r}1.492 \\
(1.150) \\
\end{array}$ & \\
\hline Island & & & & & $\begin{array}{r}- \\
1.415^{* * *} \\
(0.455)\end{array}$ & & & $\begin{array}{r}-0.001 \\
(0.509) \\
\end{array}$ \\
\hline Fragment & & & & & & $\begin{array}{l}-1.170 \\
(5.626)\end{array}$ & & \\
\hline Fragmentsq & & & & & & $\begin{array}{r}0.185 \\
(4.976) \\
\end{array}$ & & \\
\hline Cons & $\begin{array}{r}3.661 \\
(2.404) \\
\end{array}$ & $\begin{array}{r}4.175 \\
(3.146) \\
\end{array}$ & $\begin{array}{r}4.315 \\
(3.350) \\
\end{array}$ & $\begin{array}{c}-11.331 \\
(10.904) \\
\end{array}$ & $\begin{array}{c}-18.038 * \\
(10.425) \\
\end{array}$ & $\begin{array}{r}2.854 \\
(2.269) \\
\end{array}$ & $\begin{array}{r}-8.774 \\
(8.962) \\
\end{array}$ & $\begin{array}{r}3.662 \\
(2.508) \\
\end{array}$ \\
\hline Rsq & 0.5719 & 0.4589 & 0.4726 & 0.5351 & 0.5950 & 0.5878 & 0.6019 & 0.5719 \\
\hline Root MSE & .73975 & .7515 & .75715 & .72619 & .69304 & .75436 & .72696 & .75384 \\
\hline Obs & 30 & 29 & 29 & 29 & 29 & 30 & 30 & 30 \\
\hline
\end{tabular}




\section{Table 6c: Africa from 1976}

\begin{tabular}{|c|c|c|c|c|c|c|c|c|}
\hline & \multicolumn{8}{|c|}{ Log of 2006 GDP per capita in constant year 2000 dollars } \\
\hline L_ypc2k1976 & $\begin{array}{r}0.940 * * * \\
(0.117)\end{array}$ & $\begin{array}{r}0.913^{* * *} \\
(0.133)\end{array}$ & $\begin{array}{r}0.924 * * * \\
(0.124)\end{array}$ & $\begin{array}{r}0.881^{* * *} \\
(0.113)\end{array}$ & $\begin{array}{r}0.860 * * * \\
(0.121)\end{array}$ & $\begin{array}{r}1.013^{* * *} \\
(0.124)\end{array}$ & $\begin{array}{r}0.880 * * * \\
(0.107)\end{array}$ & $\begin{array}{r}0.910 * * * \\
(0.120)\end{array}$ \\
\hline L_pop1976 & $\begin{array}{l}-0.124 * \\
(0.073) \\
\end{array}$ & $\begin{array}{r}-0.086 \\
(0.110) \\
\end{array}$ & $\begin{array}{r}-0.082 \\
(0.107) \\
\end{array}$ & $\begin{array}{r}-0.104 \\
(0.120) \\
\end{array}$ & $\begin{array}{r}-0.085 \\
(0.128) \\
\end{array}$ & $\begin{array}{r}-0.002 \\
(0.082) \\
\end{array}$ & $\begin{array}{r}-0.110 \\
(0.070) \\
\end{array}$ & $\begin{array}{r}-0.104 \\
(0.084)\end{array}$ \\
\hline Tradey7680 & & $\begin{array}{r}0.002 \\
(0.006) \\
\end{array}$ & $\begin{array}{r}0.002 \\
(0.006) \\
\end{array}$ & $\begin{array}{r}0.000 \\
(0.006) \\
\end{array}$ & $\begin{array}{r}0.001 \\
(0.006) \\
\end{array}$ & & & \\
\hline L_pden1976 & & & $\begin{array}{r}0.053 \\
(0.090) \\
\end{array}$ & $\begin{array}{r}0.013 \\
(0.102) \\
\end{array}$ & $\begin{array}{r}0.000 \\
(0.105) \\
\end{array}$ & & & \\
\hline Remoteness & & & & $\begin{array}{r}1.263 \\
(1.128) \\
\end{array}$ & $\begin{array}{r}1.135 \\
(1.167) \\
\end{array}$ & & $\begin{array}{l}1.326^{*} \\
(0.757) \\
\end{array}$ & \\
\hline Island & & & & & $\begin{array}{r}0.217 \\
(0.510)\end{array}$ & & & $\begin{array}{r}0.385 \\
(0.463)\end{array}$ \\
\hline Fragment & & & & & & $\begin{array}{r}0.474 \\
(3.781) \\
\end{array}$ & & \\
\hline Fragmentsq & & & & & & $\begin{array}{r}-1.746 \\
(3.427)\end{array}$ & & \\
\hline Cons & $\begin{array}{r}2.256 \\
(1.365) \\
\end{array}$ & $\begin{array}{r}1.703 \\
(1.773) \\
\end{array}$ & $\begin{array}{r}1.421 \\
(1.819) \\
\end{array}$ & $\begin{array}{r}-8.517 \\
(8.207) \\
\end{array}$ & $\begin{array}{r}-7.612 \\
(8.468) \\
\end{array}$ & $\begin{array}{r}0.444 \\
(1.533) \\
\end{array}$ & $\begin{array}{r}-8.893 \\
(6.310) \\
\end{array}$ & $\begin{array}{r}2.102 \\
(1.424) \\
\end{array}$ \\
\hline Rsq & 0.7309 & 0.7327 & 0.7367 & 0.7530 & 0.7548 & 0.7715 & 0.7527 & 0.7387 \\
\hline Root MSE & .6172 & .62558 & .63188 & .62329 & 0.6982 & .58863 & 60171 & .61851 \\
\hline Obs & 33 & 33 & 33 & 33 & 33 & 33 & 33 & 33 \\
\hline
\end{tabular}




\section{Table 6d: Africa from 1996}

\begin{tabular}{|c|c|c|c|c|c|c|}
\hline \multirow[b]{2}{*}{ l_урс2k1996 } & \multicolumn{6}{|c|}{ Log of 2006 GDP per capita in constant year 2000 dollars } \\
\hline & $\begin{array}{r}1.009 * * * \\
(0.051) \\
\end{array}$ & $\begin{array}{r}1.052^{* * *} \\
(0.049) \\
\end{array}$ & $\begin{array}{r}1.050^{* * *} \\
(0.050) \\
\end{array}$ & $\begin{array}{r}1.017^{* * *} \\
(0.054) \\
\end{array}$ & $\begin{array}{r}1.017^{* * *} \\
(0.056) \\
\end{array}$ & $\begin{array}{r}1.009 * * * \\
(0.057) \\
\end{array}$ \\
\hline L_pop1996 & $\begin{array}{r}-0.032 \\
(0.055)\end{array}$ & $\begin{array}{r}0.042 \\
(0.028) \\
\end{array}$ & $\begin{array}{r}0.040 \\
(0.028) \\
\end{array}$ & $\begin{array}{l}0.062 * \\
(0.035) \\
\end{array}$ & $\begin{array}{l}0.062 * \\
(0.036) \\
\end{array}$ & $\begin{array}{r}0.068 * \\
(0.035) \\
\end{array}$ \\
\hline Tradey9600 & & $\begin{array}{r}0.000 \\
(0.001) \\
\end{array}$ & $\begin{array}{r}0.000 \\
(0.001) \\
\end{array}$ & $\begin{array}{r}0.000 \\
(0.002) \\
\end{array}$ & $\begin{array}{r}0.000 \\
(0.002) \\
\end{array}$ & $\begin{array}{r}0.001 \\
(0.002) \\
\end{array}$ \\
\hline l_pden1996 & & & $\begin{array}{l}-0.007 \\
(0.023)\end{array}$ & $\begin{array}{l}-0.020 \\
(0.026)\end{array}$ & $\begin{array}{l}-0.020 \\
(0.026)\end{array}$ & $\begin{array}{r}-0.029 \\
(0.030)\end{array}$ \\
\hline Wgi1996 & & & & 0.101 & 0.101 & 0.096 \\
\hline & & & & $(0.063)$ & $(0.067)$ & $(0.067)$ \\
\hline Remoteness & & & & & $\begin{array}{l}-0.002 \\
(0.304)\end{array}$ & $\begin{array}{r}-0.034 \\
(0.315)\end{array}$ \\
\hline Island & & & & & & $\begin{array}{r}0.145 \\
(0.162) \\
\end{array}$ \\
\hline Fragment & & & & & & \\
\hline Fragmentsq & & & & & & \\
\hline Cons & $\begin{array}{r}0.647 \\
(1.075) \\
\end{array}$ & $\begin{array}{r}-0.838 \\
(0.587) \\
\end{array}$ & $\begin{array}{r}-0.784 \\
(0.617) \\
\end{array}$ & $\begin{array}{l}-0.811 \\
(0.682) \\
\end{array}$ & $\begin{array}{r}-0.797 \\
(2.506) \\
\end{array}$ & $\begin{array}{r}-0.571 \\
(2.544) \\
\end{array}$ \\
\hline Rsq & 0.8966 & 0.9636 & 0.9637 & 0.9601 & 0.9601 & 0.9612 \\
\hline Root MSE & .37575 & .21367 & .21625 & .21651 & .21967 & .21992 \\
\hline Obs & 45 & 43 & 43 & 41 & 41 & 41 \\
\hline
\end{tabular}




\begin{tabular}{|c|c|c|c|c|}
\hline \multirow[b]{2}{*}{ l_ypc2k1996 } & \multicolumn{4}{|c|}{ Log of 2006 GDP per capita in constant year 2000 dollars } \\
\hline & $\begin{array}{r}1.045^{* * *} \\
(0.077) \\
\end{array}$ & $\begin{array}{r}1.011^{* * *} \\
(0.058)\end{array}$ & $\begin{array}{r}1.015^{* * *} \\
(0.052)\end{array}$ & $\begin{array}{r}1.015^{* * *} \\
(0.056) \\
\end{array}$ \\
\hline L_pop1996 & $\begin{array}{r}-0.059 \\
(0.078)\end{array}$ & $\begin{array}{l}-0.032 \\
(0.055)\end{array}$ & $\begin{array}{r}-0.041 \\
(0.068)\end{array}$ & $\begin{array}{r}0.003 \\
(0.056) \\
\end{array}$ \\
\hline Tradey9600 & & & & \\
\hline l_pden1996 & & & & \\
\hline Wgi1996 & $\begin{array}{l}-0.101 \\
(0.141)\end{array}$ & & & \\
\hline remoteness & & $\begin{array}{r}-0.025 \\
(0.303) \\
\end{array}$ & & \\
\hline Island & & & $\begin{array}{r}-0.119 \\
(0.205) \\
\end{array}$ & \\
\hline Fragment & & & & $\begin{array}{r}-0.151 \\
(1.147) \\
\end{array}$ \\
\hline Fragmentsq & & & & $\begin{array}{r}-0.215 \\
(0.973) \\
\end{array}$ \\
\hline Cons & $\begin{array}{r}0.782 \\
(1.096) \\
\end{array}$ & $\begin{array}{r}0.849 \\
(2.873) \\
\end{array}$ & $\begin{array}{r}0.764 \\
(1.231) \\
\end{array}$ & $\begin{array}{r}0.247 \\
(1.171) \\
\end{array}$ \\
\hline Rsq & 0.8865 & 0.8966 & 0.8974 & .38037 \\
\hline Root MSE & .38052 & .38029 & .37874 & 0.8991 \\
\hline Obs & 43 & 45 & 45 & 45 \\
\hline
\end{tabular}




\section{Table 7a: Africa from 1960 with Landlocked Dummy}

\begin{tabular}{|c|c|c|c|c|}
\hline \multirow[b]{2}{*}{ L_ypc2k1960 } & \multicolumn{4}{|c|}{ Log of 2006 GDP per capita in constant year 2000 dollars } \\
\hline & $\begin{array}{c}0.844 * * * \\
(0.261)\end{array}$ & $\begin{array}{l}0.760 * \\
(0.385)\end{array}$ & $\begin{array}{l}0.615^{*} \\
(0.334)\end{array}$ & $\begin{array}{c}0.472 \\
(0.303)\end{array}$ \\
\hline L_pop1960 & $\begin{array}{r}-0.220 \\
(0.213) \\
\end{array}$ & $\begin{array}{c}-0.197 \\
(0.209) \\
\end{array}$ & $\begin{array}{c}-0.237 \\
(0.211) \\
\end{array}$ & $\begin{array}{r}-0.303 \\
(0.205) \\
\end{array}$ \\
\hline Landl & $\begin{array}{c}0.110 \\
(0.390)\end{array}$ & $\begin{array}{l}0.0445 \\
(0.386)\end{array}$ & $\begin{array}{l}-0.283 \\
(0.508)\end{array}$ & $\begin{array}{r}-0.809 \\
(0.517)\end{array}$ \\
\hline Tradey6064 & $\begin{array}{l}-0.00130 \\
(0.00784)\end{array}$ & $\begin{array}{l}-0.00181 \\
(0.00823)\end{array}$ & $\begin{array}{r}-0.00892 \\
(0.0112)\end{array}$ & $\begin{array}{l}-0.0200 * * \\
(0.00926)\end{array}$ \\
\hline L_pden $1960^{1}$ & & $\begin{array}{c}-0.0948 \\
(0.227)\end{array}$ & $\begin{array}{l}-0.194 \\
(0.240) \\
\end{array}$ & $\begin{array}{r}-0.330 \\
(0.237) \\
\end{array}$ \\
\hline Remoteness & & & $\begin{array}{c}2.924 \\
(2.334) \\
\end{array}$ & $\begin{array}{c}5.354 * * \\
(2.057) \\
\end{array}$ \\
\hline Island & & & & $\begin{array}{c}-2.448 * * \\
(0.870)\end{array}$ \\
\hline Cons & $\begin{array}{c}4.422 \\
(3.897) \\
\end{array}$ & $\begin{array}{c}4.840 \\
(4.666) \\
\end{array}$ & $\begin{array}{c}-17.95 \\
(17.40) \\
\end{array}$ & $\begin{array}{c}-35.66^{* *} \\
(15.52) \\
\end{array}$ \\
\hline Rsq & 0.408 & 0.417 & 0.516 & 0.655 \\
\hline Root MSE & 0.889 & 0.907 & 0.850 & 0.740 \\
\hline Obs & 24 & 24 & 24 & 24 \\
\hline
\end{tabular}

${ }^{1}$ No data for land area in 1960, so density is 1960 population / area in 1961 


\section{Table 7b: Africa from 1968 with Landlocked Dummy}

\begin{tabular}{|c|c|c|c|c|c|c|c|c|}
\hline & \multicolumn{8}{|c|}{ Log of 2006 GDP per capita in constant year 2000 dollars } \\
\hline L_ypc2k1968 & $\begin{array}{c}0.937 * * * \\
(0.149)\end{array}$ & $\begin{array}{c}0.955^{* * *} \\
(0.205)\end{array}$ & $\begin{array}{c}0.884 * * * \\
(0.251)\end{array}$ & $\begin{array}{c}0.722 * * \\
(0.276)\end{array}$ & $\begin{array}{c}0.605^{* *} \\
(0.282)\end{array}$ & $\begin{array}{c}0.977^{* * *} \\
(0.187)\end{array}$ & $\begin{array}{c}0.836^{* * *} \\
(0.151)\end{array}$ & $\begin{array}{c}0.934^{* * *} \\
(0.157)\end{array}$ \\
\hline L_pop1968 & $\begin{array}{l}-0.154 \\
(0.114)\end{array}$ & $\begin{array}{l}-0.169 \\
(0.185)\end{array}$ & $\begin{array}{l}-0.153 \\
(0.184)\end{array}$ & $\begin{array}{c}-0.236 \\
(0.223)\end{array}$ & $\begin{array}{l}-0.341 \\
(0.209)\end{array}$ & $\begin{array}{c}-0.0815 \\
(0.137)\end{array}$ & $\begin{array}{l}-0.163 \\
(0.109)\end{array}$ & $\begin{array}{l}-0.151 \\
(0.124)\end{array}$ \\
\hline Landl & $\begin{array}{c}0.249 \\
(0.342)\end{array}$ & $\begin{array}{c}0.237 \\
(0.340)\end{array}$ & $\begin{array}{c}0.173 \\
(0.310) \\
\end{array}$ & $\begin{array}{l}-0.153 \\
(0.462)\end{array}$ & $\begin{array}{l}-0.579 \\
(0.534)\end{array}$ & $\begin{array}{c}0.226 \\
(0.343)\end{array}$ & $\begin{array}{l}0.107 \\
(0.318)\end{array}$ & $\begin{array}{c}0.253 \\
(0.345) \\
\end{array}$ \\
\hline Tradey6872 & & $\begin{array}{l}-0.00477 \\
(0.0116)\end{array}$ & $\begin{array}{c}-0.00480 \\
(0.0116)\end{array}$ & $\begin{array}{c}- \\
0.00976 \\
(0.0120)\end{array}$ & $\begin{array}{r}-0.0178 \\
(0.0106)\end{array}$ & & & \\
\hline L_pden1968 & & & $\begin{array}{c}-0.0808 \\
(0.141)\end{array}$ & $\begin{array}{l}-0.170 \\
(0.185)\end{array}$ & $\begin{array}{l}-0.270 \\
(0.201)\end{array}$ & & & \\
\hline Remoteness & & & & $\begin{array}{c}2.211 \\
(2.039)\end{array}$ & $\begin{array}{l}4.050 * \\
(2.156)\end{array}$ & & $\begin{array}{c}1.377 \\
(1.144)\end{array}$ & \\
\hline Island & & & & & $\begin{array}{c}-1.956^{* *} \\
(0.864)\end{array}$ & & & $\begin{array}{l}0.0558 \\
(0.490) \\
\end{array}$ \\
\hline Fragment & & & & & & $\begin{array}{l}-1.108 \\
(5.790)\end{array}$ & & \\
\hline Fragmentsq & & & & & & $\begin{array}{c}0.171 \\
(5.123) \\
\end{array}$ & & \\
\hline Cons & $\begin{array}{r}2.740 \\
(2.024) \\
\end{array}$ & $\begin{array}{r}3.107 \\
(2.680) \\
\end{array}$ & $\begin{array}{r}3.510 \\
(3.090) \\
\end{array}$ & $\begin{array}{r}-12.48 \\
(13.85) \\
\end{array}$ & $\begin{array}{l}-24.95 \\
(14.95) \\
\end{array}$ & $\begin{array}{r}2.057 \\
(2.548) \\
\end{array}$ & $\begin{array}{r}-8.218 \\
(8.973) \\
\end{array}$ & $\begin{array}{r}2.704 \\
(2.125) \\
\end{array}$ \\
\hline Rsq & 0.581 & 0.469 & 0.478 & 0.538 & 0.629 & 0.595 & 0.603 & 0.581 \\
\hline Root MSE & 0.746 & 0.760 & 0.770 & 0.740 & 0.679 & 0.763 & 0.740 & 0.761 \\
\hline Obs & 30 & 29 & 29 & 29 & 29 & 30 & 30 & 30 \\
\hline
\end{tabular}




\section{Table 7c: Africa from 1976 with Landlocked Dummy}

\begin{tabular}{|c|c|c|c|c|c|c|c|c|}
\hline & \multicolumn{8}{|c|}{ Log of 2006 GDP per capita in constant year 2000 dollars } \\
\hline L_ypc2k1976 & $\begin{array}{c}1.024 * * * \\
(0.134)\end{array}$ & $\begin{array}{c}1.005^{* * *} \\
(0.169)\end{array}$ & $\begin{array}{c}1.038 * * * \\
(0.150)\end{array}$ & $\begin{array}{c}0.984 * * * \\
(0.146)\end{array}$ & $\begin{array}{c}0.966^{* * *} \\
(0.147)\end{array}$ & $\begin{array}{c}1.069 * * * \\
(0.148)\end{array}$ & $\begin{array}{c}0.950 * * * \\
(0.135)\end{array}$ & $\begin{array}{c}0.998 * * * \\
(0.129)\end{array}$ \\
\hline L_pop1976 & $\begin{array}{l}-0.0962 \\
(0.0641)\end{array}$ & $\begin{array}{c}-0.0746 \\
(0.104)\end{array}$ & $\begin{array}{l}-0.0658 \\
(0.0950)\end{array}$ & $\begin{array}{l}-0.0836 \\
(0.108)\end{array}$ & $\begin{array}{l}-0.0487 \\
(0.109)\end{array}$ & $\begin{array}{l}0.00373 \\
(0.0803)\end{array}$ & $\begin{array}{l}-0.0939 \\
(0.0656)\end{array}$ & $\begin{array}{l}-0.0651 \\
(0.0713)\end{array}$ \\
\hline Landl & $\begin{array}{c}0.344 \\
(0.237) \\
\end{array}$ & $\begin{array}{c}0.334 \\
(0.255) \\
\end{array}$ & $\begin{array}{c}0.395 \\
(0.250)\end{array}$ & $\begin{array}{c}0.299 \\
(0.233)\end{array}$ & $\begin{array}{c}0.349 \\
(0.234) \\
\end{array}$ & $\begin{array}{r}0.245 \\
(0.227)\end{array}$ & $\begin{array}{c}0.240 \\
(0.245)\end{array}$ & $\begin{array}{c}0.401 \\
(0.244) \\
\end{array}$ \\
\hline Tradey7680 & & $\begin{array}{c}0.00130 \\
(0.00601)\end{array}$ & $\begin{array}{c}0.00107 \\
(0.00595)\end{array}$ & $\begin{array}{l}0.000195 \\
(0.00624)\end{array}$ & $\begin{array}{c}0.00117 \\
(0.00624)\end{array}$ & & & \\
\hline L_pden1976 & & & $\begin{array}{c}0.0810 \\
(0.0844)\end{array}$ & $\begin{array}{l}0.0493 \\
(0.101) \\
\end{array}$ & $\begin{array}{l}0.0335 \\
(0.104) \\
\end{array}$ & & & \\
\hline Remoteness & & & & $\begin{array}{c}0.797 \\
(1.055)\end{array}$ & $\begin{array}{c}0.513 \\
(1.127)\end{array}$ & & $\begin{array}{c}1.054 \\
(0.760)\end{array}$ & \\
\hline Island & & & & & $\begin{array}{r}0.353 \\
(0.425) \\
\end{array}$ & & & $\begin{array}{c}0.507 \\
(0.444) \\
\end{array}$ \\
\hline Fragment & & & & & & $\begin{array}{c}0.867 \\
(3.958)\end{array}$ & & \\
\hline Fragmentsq & & & & & & $\begin{array}{l}-1.953 \\
(3.516) \\
\end{array}$ & & \\
\hline Cons & $\begin{array}{c}1.207 \\
(1.260)\end{array}$ & $\begin{array}{c}0.904 \\
(1.504)\end{array}$ & $\begin{array}{c}0.325 \\
(1.332)\end{array}$ & $\begin{array}{l}-5.682 \\
(7.776)\end{array}$ & $\begin{array}{l}-3.744 \\
(8.361)\end{array}$ & $\begin{array}{l}-0.242 \\
(1.744)\end{array}$ & $\begin{array}{l}-7.340 \\
(6.231)\end{array}$ & $\begin{array}{c}0.831 \\
(1.228)\end{array}$ \\
\hline Rsq & 0.748 & 0.748 & 0.757 & 0.763 & 0.767 & 0.780 & 0.760 & 0.761 \\
\hline Root MSE & 0.608 & 0.618 & 0.618 & 0.623 & 0.629 & 0.589 & 0.603 & 0.602 \\
\hline Obs & 33 & 33 & 33 & 33 & 33 & 33 & 33 & 33 \\
\hline
\end{tabular}




\section{Table 7d: Africa from 1996 with Landlocked Dummy}

\begin{tabular}{|c|c|c|c|c|c|c|}
\hline & \multicolumn{6}{|c|}{ Log of 2006 GDP per capita in constant year 2000 dollars } \\
\hline L_ypc2k1996 & $\begin{array}{c}1.010 * * * \\
(0.0578)\end{array}$ & $\begin{array}{c}1.070 * * * \\
(0.0489)\end{array}$ & $\begin{array}{c}1.069 * * * \\
(0.0499)\end{array}$ & $\begin{array}{c}1.038 * * * \\
(0.0601)\end{array}$ & $\begin{array}{c}1.045^{* * * *} \\
(0.0707)\end{array}$ & $\begin{array}{c}1.045^{* * *} \\
(0.0723)\end{array}$ \\
\hline L_pop1996 & $\begin{array}{l}-0.0319 \\
(0.0562) \\
\end{array}$ & $\begin{array}{c}0.0462 \\
(0.0279) \\
\end{array}$ & $\begin{array}{c}0.0458 \\
(0.0282) \\
\end{array}$ & $\begin{array}{c}0.0626^{*} \\
(0.0355)\end{array}$ & $\begin{array}{c}0.0658 * \\
(0.0353) \\
\end{array}$ & $\begin{array}{c}0.0762 * * \\
(0.0333)\end{array}$ \\
\hline Landl & $\begin{array}{c}0.00997 \\
(0.0966)\end{array}$ & $\begin{array}{c}0.118 * \\
(0.0666)\end{array}$ & $\begin{array}{c}0.118 * \\
(0.0672)\end{array}$ & $\begin{array}{c}0.0836 \\
(0.0767)\end{array}$ & $\begin{array}{c}0.0923 \\
(0.0897)\end{array}$ & $\begin{array}{c}0.123 \\
(0.0999)\end{array}$ \\
\hline Tradey9600 & & $\begin{array}{l}0.000542 \\
(0.00137)\end{array}$ & $\begin{array}{r}0.000539 \\
(0.00138)\end{array}$ & $\begin{array}{l}0.000561 \\
(0.00162)\end{array}$ & $\begin{array}{l}0.000672 \\
(0.00167)\end{array}$ & $\begin{array}{r}0.000940 \\
(0.00165)\end{array}$ \\
\hline L_pden1996 & & & $\begin{array}{r}-0.00210 \\
(0.0216)\end{array}$ & $\begin{array}{l}-0.0145 \\
(0.0246)\end{array}$ & $\begin{array}{l}-0.0124 \\
(0.0265)\end{array}$ & $\begin{array}{l}-0.0228 \\
(0.0285)\end{array}$ \\
\hline Wgi1996 & & & & $\begin{array}{c}0.0747 \\
(0.0688) \\
\end{array}$ & $\begin{array}{c}0.0753 \\
(0.0702)\end{array}$ & $\begin{array}{c}0.0595 \\
(0.0696)\end{array}$ \\
\hline Remoteness & & & & & $\begin{array}{r}-0.102 \\
(0.358) \\
\end{array}$ & $\begin{array}{l}-0.181 \\
(0.396) \\
\end{array}$ \\
\hline Island & & & & & & $\begin{array}{c}0.201 \\
(0.154)\end{array}$ \\
\hline Fragment & & & & & & \\
\hline Fragmentsq & & & & & & \\
\hline Cons & $\begin{array}{r}0.635 \\
(1.165) \\
\end{array}$ & $\begin{array}{c}-1.066 * \\
(0.595) \\
\end{array}$ & $\begin{array}{c}-1.049 * \\
(0.617) \\
\end{array}$ & $\begin{array}{l}-1.027 \\
(0.719) \\
\end{array}$ & $\begin{array}{c}-0.264 \\
(2.780) \\
\end{array}$ & $\begin{array}{c}0.229 \\
(2.957) \\
\end{array}$ \\
\hline Rsq & 0.897 & 0.966 & 0.966 & 0.961 & 0.961 & 0.963 \\
\hline Root MSE & 0.380 & 0.209 & 0.212 & 0.216 & 0.219 & 0.217 \\
\hline Obs & 45 & 43 & 43 & 41 & 41 & 41 \\
\hline
\end{tabular}




\begin{tabular}{|c|c|c|c|c|}
\hline & \multicolumn{4}{|c|}{ Log of 2006 GDP per capita in constant year 2000 dollars } \\
\hline L_ypc2k1996 & $\begin{array}{c}1.061^{* * *} \\
(0.0904)\end{array}$ & $\begin{array}{c}1.013^{* * *} \\
(0.0684)\end{array}$ & $\begin{array}{c}1.015^{* * *} \\
(0.0573)\end{array}$ & $\begin{array}{c}1.014 * * * \\
(0.0619)\end{array}$ \\
\hline L_pop1996 & $\begin{array}{l}-0.0593 \\
(0.0793)\end{array}$ & $\begin{array}{l}-0.0316 \\
(0.0565)\end{array}$ & $\begin{array}{l}-0.0412 \\
(0.0715)\end{array}$ & $\begin{array}{l}0.00360 \\
(0.0554)\end{array}$ \\
\hline Landl & $\begin{array}{c}0.0664 \\
(0.0879)\end{array}$ & $\begin{array}{l}0.0121 \\
(0.102)\end{array}$ & $\begin{array}{c}-0.00331 \\
(0.115)\end{array}$ & $\begin{array}{l}-0.0125 \\
(0.107)\end{array}$ \\
\hline Tradey9600 & & & & \\
\hline L_pden1996 & & & & \\
\hline Wgi1996 & $\begin{array}{l}-0.122 \\
(0.150) \\
\end{array}$ & & & \\
\hline Remoteness & & $\begin{array}{l}-0.0353 \\
(0.323) \\
\end{array}$ & & \\
\hline Island & & & $\begin{array}{l}-0.120 \\
(0.231) \\
\end{array}$ & \\
\hline Fragment & & & & $\begin{array}{l}-0.141 \\
(1.158) \\
\end{array}$ \\
\hline Fragmentsq & & & & $\begin{array}{l}-0.229 \\
(0.986) \\
\end{array}$ \\
\hline Cons & $\begin{array}{c}0.661 \\
(1.146)\end{array}$ & $\begin{array}{c}0.917 \\
(2.864)\end{array}$ & $\begin{array}{c}0.769 \\
(1.372)\end{array}$ & $\begin{array}{c}0.253 \\
(1.211)\end{array}$ \\
\hline Rsq & 0.887 & 0.897 & 0.897 & 0.899 \\
\hline Root MSE & 0.384 & 0.385 & 0.383 & 0.385 \\
\hline Obs & 43 & 45 & 45 & 45 \\
\hline
\end{tabular}

